\title{
Estimating global and North American methane emissions with high spatial resolution using GOSAT satellite data
}

\author{
A. J. Turner ${ }^{1}$, D. J. Jacob ${ }^{1,2}$, K. J. Wecht ${ }^{2}$, J. D. Maasakkers ${ }^{1}$, E. Lundgren ${ }^{1}$, A. E. Andrews ${ }^{3}$, S. C. Biraud ${ }^{4}$, \\ H. Boesch ${ }^{5,6}$, K. W. Bowman ${ }^{7}$, N. M. Deutscher ${ }^{8,9}$, M. K. Dubey ${ }^{10}$, D. W. T. Griffith ${ }^{8}$, F. Hase ${ }^{11}$, A. Kuze ${ }^{12}$, J. Notholt ${ }^{9}$, \\ H. Ohyama ${ }^{12,13}$, R. Parker ${ }^{5,6}$, V. H. Payne ${ }^{7}$, R. Sussmann ${ }^{14}$, C. Sweeney ${ }^{3,15}$, V. A. Velazco $^{8}$, T. Warneke ${ }^{9}$, \\ P. O. Wennberg ${ }^{16}$, and D. Wunch ${ }^{16}$ \\ ${ }^{1}$ School of Engineering and Applied Sciences, Harvard University, Cambridge, Massachusetts, USA \\ ${ }^{2}$ Department of Earth and Planetary Sciences, Harvard University, Cambridge, Massachusetts, USA \\ ${ }^{3}$ NOAA Earth System Research Laboratory, Boulder, Colorado, USA \\ ${ }^{4}$ Lawrence Berkeley National Laboratory, Berkeley, California, USA \\ ${ }^{5}$ Earth Observation Science Group, Department of Physics and Astronomy, University of Leicester, Leicester, UK \\ ${ }^{6}$ National Centre for Earth Observation, University of Leicester, Leicester, UK \\ ${ }^{7}$ Jet Propulsion Laboratory/California Institute of Technology, Pasadena, California, USA \\ ${ }^{8}$ Centre for Atmospheric Chemistry, University of Wollongong, NSW, Australia \\ ${ }^{9}$ Institute of Environmental Physics, University of Bremen, Bremen, Germany \\ ${ }^{10}$ Los Alamos National Laboratory, Los Alamos, New Mexico, USA \\ ${ }^{11}$ Karlsruhe Institute of Technology, IMK-ASF, Karlsruhe, Germany \\ ${ }^{12}$ Japan Aerospace Exploration Agency, Tsukuba, Ibaraki, Japan \\ ${ }^{13}$ Solar-Terrestrial Environment Laboratory, Nagoya University, Nagoya, Aichi, Japan \\ ${ }^{14}$ Karlsruhe Institute of Technology, IMK-IFU, Garmisch-Partenkirchen, Germany \\ ${ }^{15}$ Cooperative Institute for Research in Environmental Sciences, University of Colorado at Boulder, Boulder, Colorado, USA \\ ${ }^{16}$ California Institute of Technology, Pasadena, California, USA
}

Correspondence to: A. J. Turner (aturner@fas.harvard.edu)

Received: 04 December 2014 - Published in Atmos. Chem. Phys. Discuss.: 18 February 2015

Revised: 15 June 2015 - Accepted: 17 June 2015 - Published: 30 June 2015

\begin{abstract}
We use 2009-2011 space-borne methane observations from the Greenhouse Gases Observing SATellite (GOSAT) to estimate global and North American methane emissions with $4^{\circ} \times 5^{\circ}$ and up to $50 \mathrm{~km} \times 50 \mathrm{~km}$ spatial resolution, respectively. GEOS-Chem and GOSAT data are first evaluated with atmospheric methane observations from surface and tower networks (NOAA/ESRL, TCCON) and aircraft (NOAA/ESRL, HIPPO), using the GEOS-Chem chemical transport model as a platform to facilitate comparison of GOSAT with in situ data. This identifies a high-latitude bias between the GOSAT data and GEOS-Chem that we correct via quadratic regression. Our global adjoint-based inversion yields a total methane source of $539 \mathrm{Tga}^{-1}$ with some important regional corrections to the EDGARv4.2 inventory used as a prior. Results serve as dynamic bound-
\end{abstract}

ary conditions for an analytical inversion of North American methane emissions using radial basis functions to achieve high resolution of large sources and provide error characterization. We infer a US anthropogenic methane source of 40.2 $42.7 \mathrm{Tg} \mathrm{a}^{-1}$, as compared to $24.9-27.0 \mathrm{Tg} \mathrm{a}^{-1}$ in the EDGAR and EPA bottom-up inventories, and $30.0-44.5 \mathrm{Tg} \mathrm{a}^{-1}$ in recent inverse studies. Our estimate is supported by independent surface and aircraft data and by previous inverse studies for California. We find that the emissions are highest in the southern-central US, the Central Valley of California, and Florida wetlands; large isolated point sources such as the US Four Corners also contribute. Using prior information on source locations, we attribute $29-44 \%$ of US anthropogenic methane emissions to livestock, $22-31 \%$ to oil/gas, 
$20 \%$ to landfills/wastewater, and $11-15 \%$ to coal. Wetlands contribute an additional 9.0-10.1 $\mathrm{Tg} \mathrm{a}^{-1}$.

\section{Introduction}

Methane $\left(\mathrm{CH}_{4}\right)$ emissions have contributed $0.97 \mathrm{~W} \mathrm{~m}^{-2}$ in global radiative forcing of climate since pre-industrial times, second only to $\mathrm{CO}_{2}$ with $1.7 \mathrm{~W} \mathrm{~m}^{-2}$ (IPCC, 2013). As a short-lived climate forcing agent (lifetime $\sim 10$ years), methane may provide a lever for slowing near-term climate change (Ramanathan and Xu, 2010; Shindell et al., 2012). Major anthropogenic sources include natural gas and petroleum production and use, coal mining, waste (landfills and wastewater treatment), livestock, and rice cultivation. Wetlands are the largest natural source. The presentday global emission of methane is $550 \pm 60 \mathrm{Tga}^{-1}$, constrained by knowledge of the global tropospheric hydroxyl radical $(\mathrm{OH})$ concentration from the methylchloroform budget (Prather et al., 2012). However, allocation by source types and regions is very uncertain (Dlugokencky et al., 2011). Here we use GOSAT space-borne observations for 20092011 to improve our understanding of global and North American methane emissions using a high-resolution inversion technique (Turner and Jacob, 2015).

The US Environmental Protection Agency (EPA) produces national emission inventories for anthropogenic methane, with a total of $27.0 \mathrm{Tga}^{-1}$ in 2012 including $34 \%$ from livestock, $29 \%$ from oil/gas extraction and use, $21 \%$ from waste, and $11 \%$ from coal mining (EPA, 2014). Inverse studies using observations of atmospheric methane concentrations suggest that the EPA inventory may be too low by up to a factor of 2, although they differ as to the magnitude and cause of the underestimate (Katzenstein et al., 2003; Kort et al., 2008; Xiao et al., 2008; Karion et al., 2013; Miller et al., 2013; Wecht et al., 2014a; Caulton et al., 2014). There is strong national and international interest in regulating methane emissions (President's Climate Action Plan, 2013; President's Climate Action Plan, 2014; Climate and Clean Air Coalition, 2014), particularly in the context of increasing natural gas exploitation and fracking, but uncertainty in the emission inventory makes regulation problematic.

Space-borne observations of atmospheric methane concentrations in the shortwave infrared (SWIR) are a unique resource for constraining methane emissions because of the dense and continuous data that they provide. SWIR instruments measure column concentrations with near-uniform vertical sensitivity down to the surface. Data are available from the SCIAMACHY instrument for 2003-2012 (Frankenberg et al., 2005, 2011) and from the TANSO-FTS instrument aboard GOSAT for 2009-present (Butz et al., 2011; Parker et al., 2011; hereafter we refer to the instrument as "GOSAT"). GOSAT has higher precision and pixel resolution than SCIAMACHY $(0.6 \%$ and $10 \mathrm{~km} \times 10 \mathrm{~km}$ vs. $1.5 \%$ and $30 \mathrm{~km} \times 60 \mathrm{~km}$ ), but the observations are not as dense. The GOSAT retrievals are in good agreement with surfacebased column measurements (Parker et al., 2011; Butz et al., 2011; Schepers et al., 2012; Fraser et al., 2013; Monteil et al., 2013; Cressot et al., 2014; Alexe et al., 2015).

Previous inversions of methane emissions using satellite data have mainly focused on the global scale, optimizing emissions with coarse spatial resolution (Bergamaschi et al., 2007, 2009, 2013; Fraser et al., 2013; Monteil et al., 2013; Cressot et al., 2014; Alexe et al., 2015). This limits the interpretation of the results because emissions from different source types have large spatial overlap (Fung et al., 1991). Spatial overlap is reduced at higher resolution; thus, optimizing emissions at high spatial resolution can help improve source attribution. Wecht et al. (2014a) used SCIAMACHY data for July-August 2004 in a higherresolution $(\sim 100 \mathrm{~km} \times 100 \mathrm{~km})$ inversion of methane emissions in North America, but they were unable to achieve such a resolution using GOSAT because of the sparser data (Wecht et al., 2014b).

Here we use three years (2009-2011) of GOSAT data to constrain global and North American methane emissions with high spatial resolution, exploiting both the longer record and a new analytical inversion method where the state vector of emissions is defined optimally from a set of radial basis functions (Turner and Jacob, 2015). We begin by evaluating the GOSAT retrievals with surface, aircraft, and total column observations using the GEOS-Chem chemical transport model (CTM; described in the Appendix) as an intercomparison platform. This identifies a high-latitude bias between GOSAT and GEOS-Chem that we correct. We then use GOSAT observations to constrain global methane sources with the GEOS-Chem model and its adjoint at $4^{\circ} \times 5^{\circ}$ resolution, and apply the results as boundary conditions to optimize North American methane sources with up to $50 \mathrm{~km} \times 50 \mathrm{~km}$ resolution and error characterization.

\section{GOSAT observations and bias correction}

GOSAT (Kuze et al., 2009) was launched in January 2009 by the Japan Aerospace Exploration Agency (JAXA). Methane abundance is determined by analysis of the spectrum of backscattered solar radiances in the SWIR near $1.6 \mu \mathrm{m}$. Data are available from April 2009 on. GOSAT is in Sunsynchronous low earth orbit with an Equator overpass of 12:45-13:15 LT. The instrument observes five cross-track nadir pixels (three cross-track pixels after August 2010) with a footprint diameter of $10.5 \mathrm{~km}$, a cross-track spacing of about $100 \mathrm{~km}$, an along-track spacing of 90-280 km, and a 3day revisit time. We use the version 4 proxy methane retrievals from Parker et al. (2011) that pass all quality flags (http://www.leos.le.ac.uk/GHG/data/styled/index.html). The retrievals provide a weighted column average dry-mole fraction of $\mathrm{CH}_{4}, \mathrm{X}_{\mathrm{CH}_{4}}$, with averaging kernels to describe the 
vertical weighting. The averaging kernels show near-uniform vertical sensitivity in the troposphere and decreasing sensitivity above the tropopause (see Butz et al., 2010). The estimated single-retrieval precision is scene-dependent and averages 13.3 ppb or $0.8 \%$ (Parker et al., 2011).

Figure 1 shows the mean methane concentrations for June 2009-December 2011 observed by GOSAT and used in this work. There are 590675 global observations including 74687 for the North American window of our highresolution inversion. The GOSAT sampling strategy of consistently revisiting the same locations provides a high density of observations over the sampled locations, but the coverage is not continuous (gray areas in Fig. 1). There are data over oceans from Sun glint retrievals (Butz et al., 2011) but not in the Parker et al. (2011) product used here. Methane concentrations are highest over East Asia where rice, livestock, and fossil fuels contribute large sources. They are also high over the eastern US. Low concentrations over elevated terrain (Tibetan Plateau, western US) reflect in part a larger relative contribution of the stratosphere to the column-average mixing ratio. We see from Fig. 1 that relevant spatial differences in methane mixing ratio for our inversion are of the order of $10 \mathrm{ppb}$. With a mean single-scene instrument precision of $13.3 \mathrm{ppb}$, reducible by temporal or spatial averaging, GOSAT cannot resolve day-to-day variability of emissions, but can strongly constrain a multi-year average.

Previous studies have validated the GOSAT data with surface-based FTIR methane column abundances from the Total Carbon Column Observing Network (TCCON; Wunch et al., 2011). These studies have generally found GOSAT retrievals to be within their stated precisions (Parker et al., 2011). Schepers et al. (2012) pointed out that a full validation of the GOSAT retrievals would require a more extensive validation network than is available from TCCON. Satellite observations by solar backscatter tend to be subject to highlatitude biases because of large solar zenith angles, resulting in longer path lengths and higher interference with clouds. Monteil et al. (2013) did not include a latitudinal bias correction in their inverse analysis of GOSAT data, but Cressot et al. (2014) used a bias correction based on the geometric air mass factor and Fraser et al. (2013) added a latitudinal bias correction that was fitted as part of the inversion.

The Parker et al. (2011) retrieval uses $\mathrm{CO}_{2}$ as a proxy for the light path to minimize common spectral artifacts from aerosol scattering and instrument effects (Frankenberg et al., 2005; Butz et al., 2010):

$X_{\mathrm{CH}_{4}}=\frac{X_{\mathrm{CH}_{4}}^{*}}{X_{\mathrm{CO}_{2}}^{*}} X_{\mathrm{CO}_{2}}$

where $X_{\mathrm{CH}_{4}}^{*}$ and $X_{\mathrm{CO}_{2}}^{*}$ are the dry-air mole fractions retrieved from GOSAT under the assumption of a nonscattering atmosphere and $X_{\mathrm{CO}_{2}}$ is the column-average dryair mole fraction of $\mathrm{CO}_{2}$, estimated from the LMDZ global CTM with $3.75^{\circ} \times 2.5^{\circ}$ spatial resolution. This could lead to

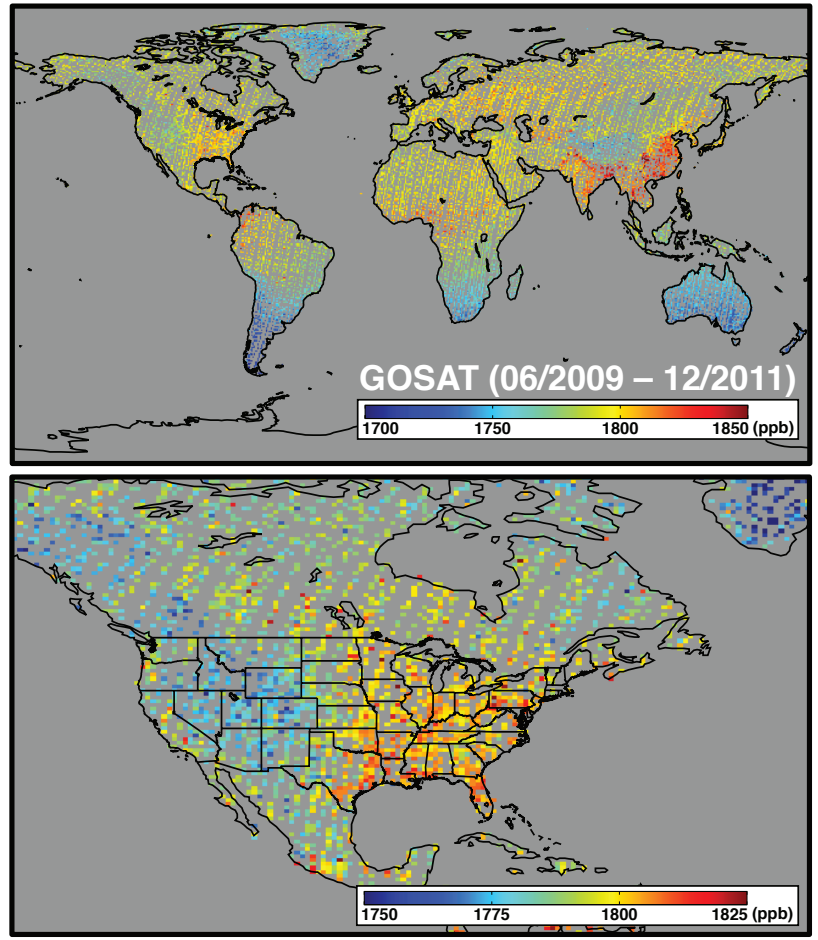

Figure 1. Mean GOSAT observations of the weighted columnaverage methane dry-mole fraction $\left(X_{\mathrm{CH}_{4}}\right)$ for June 2009 December 2011, globally and for North America. The data are version 4 proxy methane retrievals from Parker et al. (2011) that pass all quality flags (http://www.leos.le.ac.uk/GHG/data/styled/index. html).

localized bias in areas of concentrated $\mathrm{CO}_{2}$ sources. We determined the extent of the bias by replacing $X_{\mathrm{CO}_{2}}$ in Eq. (1) with (sparser) $X_{\mathrm{CO}_{2}}$ data from a full-physics GOSAT retrieval. This indicates a $14 \mathrm{ppb}$ low bias in Los Angeles but much weaker biases on regional scales.

Here we examined the consistency of GOSAT with a large body of independent surface and aircraft measurements of methane concentrations by using the GEOSChem CTM with prior methane emissions (Table 1 and Figs. A1 and A2) as an intercomparison platform. Table 2 gives summary comparison statistics and more details are in the Appendix (Figs. A3-A5). Global comparisons with HIPPO II-V aircraft profiles across the Pacific (http://hippo.ornl.gov; Wofsy, 2011), the NOAA cooperative flask sampling network (http://www.esrl.noaa.gov/ gmd/ccgg/flask.php), and the TCCON network (http://tccon. ornl.gov, GGG2014 version; Washenfelder et al., 2006; Deutscher et al., 2010; Wunch et al., 2010, 2011; Messerschmidt et al., 2011, 2012; Geibel et al., 2012) show that GEOS-Chem accurately simulates the global features of the methane distribution including the meridional gradient in different seasons, with no significant bias across multiple years and seasons (Figs. A3-A5). One would then expect simi- 
Table 1. 2009-2011 methane emissions ${ }^{\mathrm{a}}$.

\begin{tabular}{|c|c|c|c|c|c|c|}
\hline \multirow[t]{2}{*}{ Source type } & \multicolumn{2}{|c|}{ Contiguous US } & \multicolumn{2}{|c|}{ North America } & \multicolumn{2}{|c|}{ Global } \\
\hline & Prior & Posterior $^{\mathrm{b}}$ & Prior & Posterior $^{\mathrm{b}}$ & Prior & Posterior \\
\hline Total & 31.4 & $51.3-52.5$ & 63.3 & $88.5-91.3$ & 537 & 539 \\
\hline Wetlands & 5.9 & $9.0-10.1$ & 20.4 & $22.9-23.7$ & 164 & 169 \\
\hline Livestock & 8.9 & $12.6-17.0$ & 14.5 & $20.0-25.7$ & 111 & 116 \\
\hline Oil/gas & 5.4 & $8.7-13.4$ & 10.8 & $15.5-22.3$ & 69 & 67 \\
\hline Waste ${ }^{c}$ & 5.5 & $8.0-8.5$ & 9.7 & $13.4-14.5$ & 60 & 65 \\
\hline Coal & 4.0 & $4.7-6.5$ & 4.3 & 5.0-6.8 & 47 & 30 \\
\hline Rice & 0.4 & $0.8-0.9$ & 0.5 & $0.9-1.0$ & 38 & 45 \\
\hline Open fires & 0.1 & 0.1 & 1.0 & 0.9 & 17 & 16 \\
\hline Other ${ }^{\mathrm{d}}$ & 1.1 & $1.6-1.7$ & 2.2 & $3.0-3.3$ & 31 & 32 \\
\hline Natural $^{\mathrm{e}}$ & 7.5 & $9.8-11.1$ & 25.0 & $25.1-26.2$ & 176 & 181 \\
\hline Anthropogenic ${ }^{f}$ & 25.0 & $40.2-42.7$ & 41.9 & $62.3-66.2$ & 361 & 358 \\
\hline $\begin{array}{l}\text { a Emissions are in } \mathrm{Tg} \mathrm{a}^{-} \\
\text {Pickett-Heaps et al. (201 } \\
\text { b Range from two invers } \\
{ }^{c} \text { Including landfills and } \\
{ }^{\mathrm{d}} \text { Including fuel combus } \\
{ }^{\mathrm{e}} \text { Including wetlands, op } \\
{ }^{\mathrm{f}} \text { Including livestock, oil }\end{array}$ & $\begin{array}{l}\text { 1) for wet } \\
\text { ons with } \\
\text { waste wat } \\
\text { ion, termi } \\
\text { en fires, te } \\
\text { gas, wast }\end{array}$ & $\begin{array}{l}\text { ifferent assump } \\
\text { r. } \\
\text { es, and soil abso } \\
\text { mites, and soil } \\
\text { coal, rice, and }\end{array}$ & or prior & 4.2 for anthro & 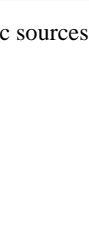 & \\
\hline
\end{tabular}

lar agreement in the comparison of GEOS-Chem to GOSAT. Comparing GEOS-Chem at $4^{\circ} \times 5^{\circ}$ over North America with TCCON, the NOAA/ESRL Global Greenhouse Gas Reference Network (surface flasks, tall tower network, and vertical profiles from the aircraft program) (http://www.esrl. noaa.gov/gmd/ccgg/flask.php; Andrews et al., 2014; Biraud et al., 2013) shows weaker correlations $\left(R^{2}=0.40-0.60\right)$ and the reduced-major-axis regression slopes (0.67-0.75) suggest a $\sim 30 \%$ prior underestimate of North American emissions. Reduction of this bias will provide an independent check on our inversion results.

Figure 2 compares the GOSAT methane observations $\left(X_{\mathrm{CH}_{4}}\right)$ to GEOS-Chem values sampled at the location and time of the observations, and with local averaging kernels applied. There is a latitudinal background pattern in the difference between GEOS-Chem and GOSAT. The bias becomes significant at latitudes poleward of $50^{\circ}$. Since GEOSChem is unbiased in its simulation of the tropospheric meridional gradient relative to the surface and aircraft data (Table 2, Fig. A3), we attribute the high-latitude bias to errors in either the GOSAT retrieval or GEOS-Chem stratospheric methane. Bias corrections that are a function of latitude or air mass factor (solar zenith angle) should be able to correct for this. However, a bias in the GOSAT data would be expected to correlate better with the air mass factor, while a bias in the model stratosphere may correlate better with latitude. We find latitude to be a better bias predictor based on the Bayesian information criterion (quadratic regression in Fig. 2c). This suggests a potential bias in the GEOS-Chem simulation of methane in the polar stratosphere, which warrants further investigation with observations such as TCCON partial columns (Saad et al., 2014; Wang et al., 2014). In any case, we remove the bias using the quadratic regression and Fig. 2d shows the resulting mean differences between GEOSChem and GOSAT after this bias correction. The differences point to errors in the GEOS-Chem prior emissions that we will correct in the inversion.

\section{Global inversion of methane emissions}

We use the bias-corrected GOSAT data to infer global methane emissions at $4^{\circ} \times 5^{\circ}$ resolution with an adjointbased four-dimensional variational data assimilation system (Henze et al., 2007; Wecht et al., 2012, 2014a). The system minimizes a cost function $(\mathcal{J})$ with Gaussian errors,

$$
\begin{aligned}
\mathcal{J}(\boldsymbol{x}) & =\frac{1}{2}(\boldsymbol{y}-\mathbf{K} \boldsymbol{x})^{T} \mathbf{S}_{\mathrm{O}}^{-1}(\boldsymbol{y}-\mathbf{K} \boldsymbol{x}) \\
& +\frac{1}{2}\left(\boldsymbol{x}_{\mathrm{a}}-\boldsymbol{x}\right)^{T} \mathbf{S}_{\mathrm{a}}^{-1}\left(\boldsymbol{x}_{\mathrm{a}}-\boldsymbol{x}\right)
\end{aligned}
$$

Here $\boldsymbol{x}_{\mathrm{a}}$ is the vector of prior emissions (see Table 1 and Fig. A1), $\boldsymbol{y}$ is the vector of GOSAT observations, $\mathbf{K}=\partial \boldsymbol{y} / \partial \boldsymbol{x}$ is the Jacobian matrix of the GEOS-Chem methane simulation used as a forward model, and $\mathbf{S}_{\mathrm{a}}$ and $\mathbf{S}_{\mathrm{O}}$ are the prior and observational error covariance matrices, respectively.

The state vector consists of scaling factors for emissions at $4^{\circ} \times 5^{\circ}$ resolution for June $2009-$ December 2011 . The prior emissions are mainly from the EDGARv4.2 inventory for anthropogenic sources (European Commission, 2011), and Pickett-Heaps et al. (2011) for wetlands. Table 1 gives a summary and further details are in the Appendix. The error covariance matrices are taken to be diagonal, implying no error 
Table 2. GEOS-Chem comparison to 2009-2011 suborbital methane observations ${ }^{\mathrm{a}}$.

\begin{tabular}{|c|c|c|c|c|c|c|}
\hline \multirow[t]{2}{*}{ Observations } & \multicolumn{2}{|c|}{$R^{2}$} & \multicolumn{2}{|c|}{ Slope ${ }^{b}$} & \multicolumn{2}{|c|}{ Mean Bias ${ }^{c}$} \\
\hline & Prior & Posterior & Prior & Posterior & Prior & Posterior \\
\hline \multicolumn{7}{|l|}{ Global } \\
\hline HIPPO (II-V) & 0.94 & 0.94 & 0.97 & 0.95 & 4.2 & 4.4 \\
\hline TCCON & 0.82 & 0.83 & 0.94 & 0.98 & 6.4 & 8.1 \\
\hline NOAA/ESRL surface flasks & 0.66 & 0.66 & 1.08 & 1.04 & 16.1 & 14.1 \\
\hline \multicolumn{7}{|l|}{ North America } \\
\hline NOAA/ESRL tall tower network & 0.40 & 0.48 & 0.72 & 1.03 & -13.3 & 3.1 \\
\hline NOAA/ESRL aircraft program & 0.54 & 0.61 & 0.75 & 0.94 & -0.2 & 6.7 \\
\hline NOAA/ESRL surface flasks & 0.60 & 0.67 & 0.67 & 1.01 & -5.6 & 7.1 \\
\hline
\end{tabular}

a GEOS-Chem at $4^{\circ} \times 5^{\circ}$ resolution globally and $1 / 2^{\circ} \times 2 / 3^{\circ}$ resolution for North America, using either prior emissions (Table 1 and Figs. A3 and A4) or posterior emissions optimized with the inversion. Further details on the comparisons are in Figs. A3-A5. NOAA observations are from the NOAA/ESRL Greenhouse Gas Reference Network. References for the observations are given in the text.

b Slope (in $\mathrm{ppb} \mathrm{ppb}^{-1}$ ) is from a reduced-major-axis (RMA) regression.

${ }^{\mathrm{c}}$ Mean bias is the mean difference (in ppb) between model and observations.

(a) Mean GEOS-Chem - GOSAT difference

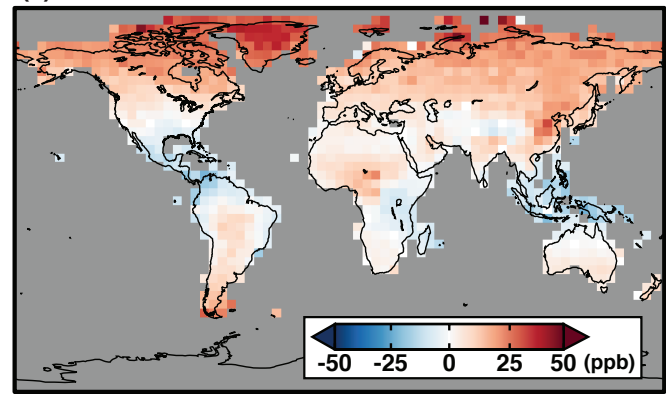

(c) Mean difference vs. latitude

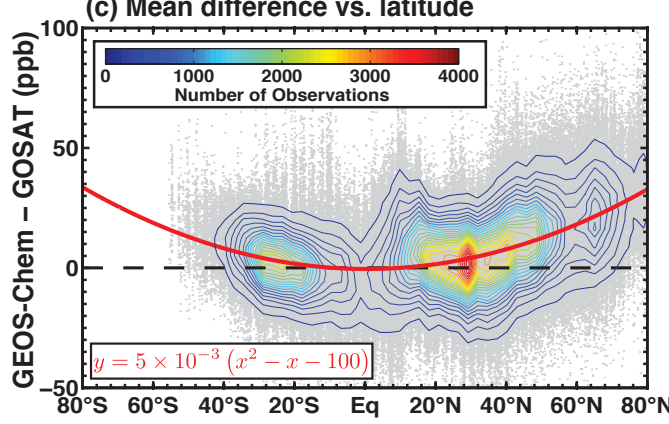

(b) Residual standard deviation

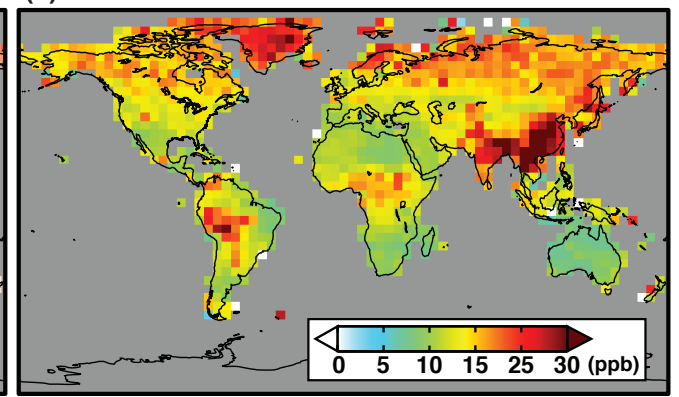

(d) Mean difference after bias removal

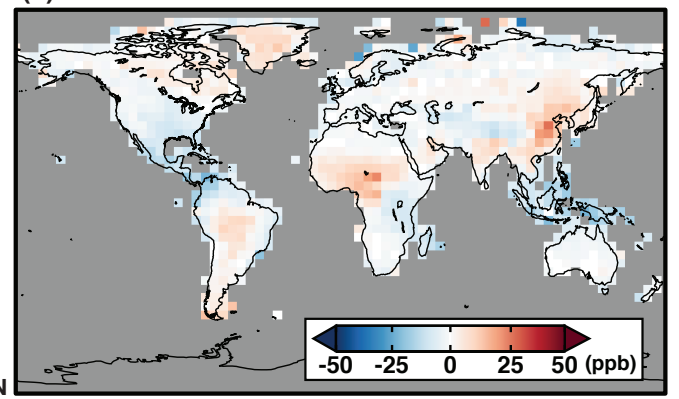

Figure 2. Comparison of the GOSAT observations from Fig. 1 to the GEOS-Chem model with prior emissions. (a and b) show the mean bias and residual standard deviation for the model-satellite difference. (c) shows the model-satellite difference as a function of latitude for individual observations along with the data density (contours), and a quadratic regression (red line; $x$ in degrees latitude, $y$ in ppb) as an estimate of the bias. The regression excludes grid squares with residual standard deviation in excess of 20 ppb as model bias in prior emissions could dominate the difference. (d) is the same as (a) but using the bias correction from (c).

correlation on the $4^{\circ} \times 5^{\circ}$ grid. We assume $50 \%$ error variance on the prior for $4^{\circ} \times 5^{\circ}$ grid cells as in Monteil et al. (2013).

Observational error variances are estimated following Heald et al. (2004) by using residual standard deviations of the differences between observations and the GEOS-Chem simulation with prior emissions, as shown in Fig. $2 b$. As shown by Heald et al. (2004), this residual error provides an estimate of the total observational error needed for the inversion, summing the contributions from instrument retrieval, representation, and model transport errors. We find that the resulting observational error variances are lower than the local retrieval error variances reported by Parker et al. (2011) for $58 \%$ of the observations, and in those cases we use the 
latter instead. The implication is that the Parker et al. (2011) error estimates may be too high but provide a conservative estimate of the observational error.

The GEOS-Chem forward model and its adjoint are as described by Wecht et al. (2014a). We optimize methane emissions from 1 June 2009 to 1 January 2012. The forward model is initialized on 1 January 2009 with concentrations from Wecht et al. (2014a). There is no significant global bias in the simulation, as discussed above. The 5-month spin-up allows for the establishment of gradients driven by synoptic motions and effectively removes the influence of the initial conditions.

Figure 3 shows the prior and posterior 2009-2011 emissions. We evaluated the posterior emissions in a GEOSChem forward simulation by comparison with the global independent observational data sets of Table 2 . The prior simulation showed high correlation and little bias. The posterior simulation shows similar results. The increase in mean bias relative to the TCCON data is not significant. As pointed out above, the global data sets mainly test the global emissions and large-scale meridional gradients. Since we used them previously to justify a bias correction in the comparison between GEOS-Chem and GOSAT, they do not provide a true independent test of the inversion results. Nevertheless, we see that the inversion does not degrade the successful simulation of the background meridional gradient in the prior GEOS-Chem simulation.

The total posterior methane emission is $539 \mathrm{Tg} \mathrm{a}^{-1}$, unchanged from the prior $\left(537 \mathrm{Tg} \mathrm{a}^{-1}\right)$. This source is within the $548_{-22}^{+21} \mathrm{Tg} \mathrm{a}^{-1}$ range of current estimates reported by Kirschke et al. (2013) and IPCC (2013). However, we find large regional differences compared to the prior. Emissions from China are revised downward by $50 \%$ from 29.2 to 14.7 $\mathrm{Tg} \mathrm{a}^{-1}$, consistent with Bergamaschi et al. (2013), who find that EDGARv4.2 Chinese coal emissions are too large. This overestimate in Chinese methane emissions is also seen by Bruhwiler et al. (2014), who assimilated the 2000-2010 NOAA surface observations into CarbonTracker using an ensemble Kalman filter. Emissions in India are also too high, while emissions in Southeast Asia are too low. Emissions from wetlands in central Africa are too high. Emissions in northern South America are too low. Corrections in North America are discussed in the next section.

We inferred the contributions from different source types to our posterior emissions by assuming that the prior inventory correctly partitions the methane by source type (see Appendix and Table 1) in each $4^{\circ} \times 5^{\circ}$ grid cell. This does not assume that the global distribution of source types is correct in the prior, only that the local identification of dominant sources is. We find only modest changes to the global partitioning by source types, with the exception of coal and rice, partly reflecting regional offsets. For example, wetland emissions increase globally by only $5 \mathrm{Tga}^{-1}$ but decrease by $24 \mathrm{Tga}^{-1}$ in the African wetlands, while increasing by $10 \mathrm{Tg} \mathrm{a}^{-1}$ in northern South America.

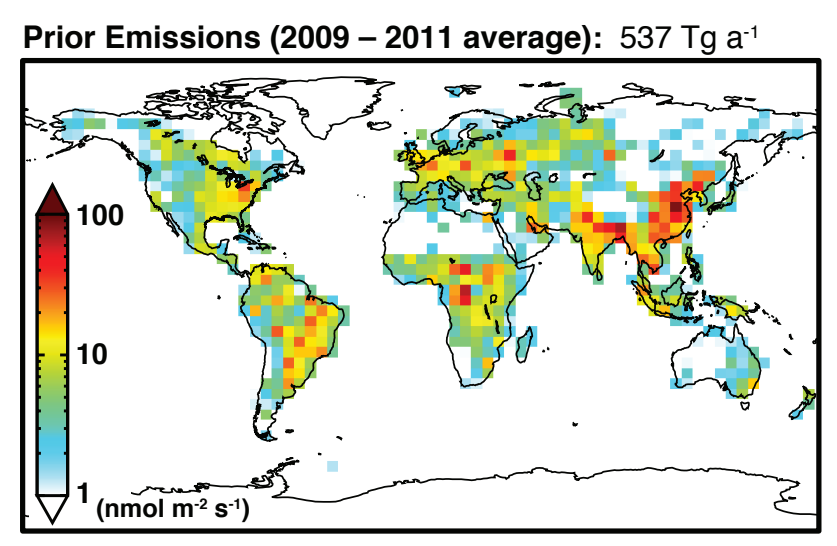

Posterior Emissions: $539 \mathrm{Tg} \mathrm{a}^{-1}$

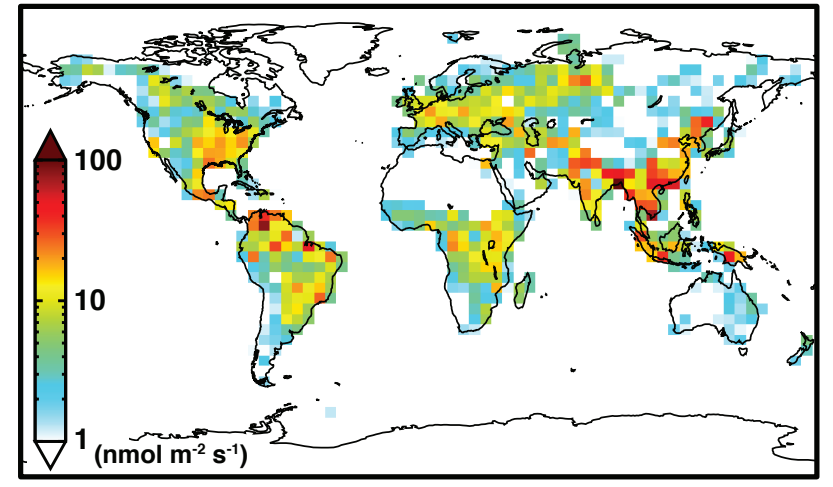

Emission Scaling Factors (Posterior / Prior): $+2 \mathrm{Tg} \mathrm{a}^{-1}$

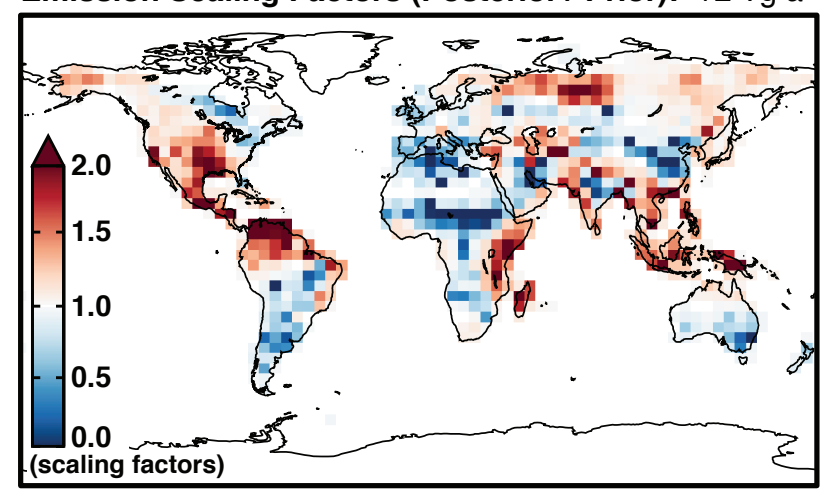

Figure 3. Optimization of methane emissions for 2009-2011 at $4^{\circ} \times 5^{\circ}$ horizontal resolution using GOSAT observations. The panels show prior emissions, posterior emissions, and the ratio between the two.

\section{North American inversion of methane emissions}

We optimize methane emissions over North America by using the nested GEOS-Chem simulation at $1 / 2^{\circ} \times 2 / 3^{\circ}$ horizontal resolution $(\sim 50 \mathrm{~km} \times 50 \mathrm{~km})$ over the North American window in Fig. 1. Time-dependent boundary conditions for this nested simulation are from the global model at $4^{\circ} \times 5^{\circ}$ horizontal resolution using the posterior emissions derived above. We only solve for the spatial distribution of emissions, assuming that the prior temporal distribution is 


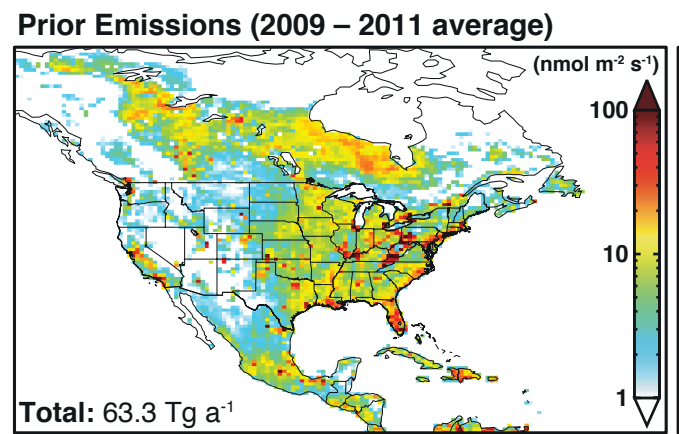

Averaging Kernel Sensitivity

Posterior Methane Emissions
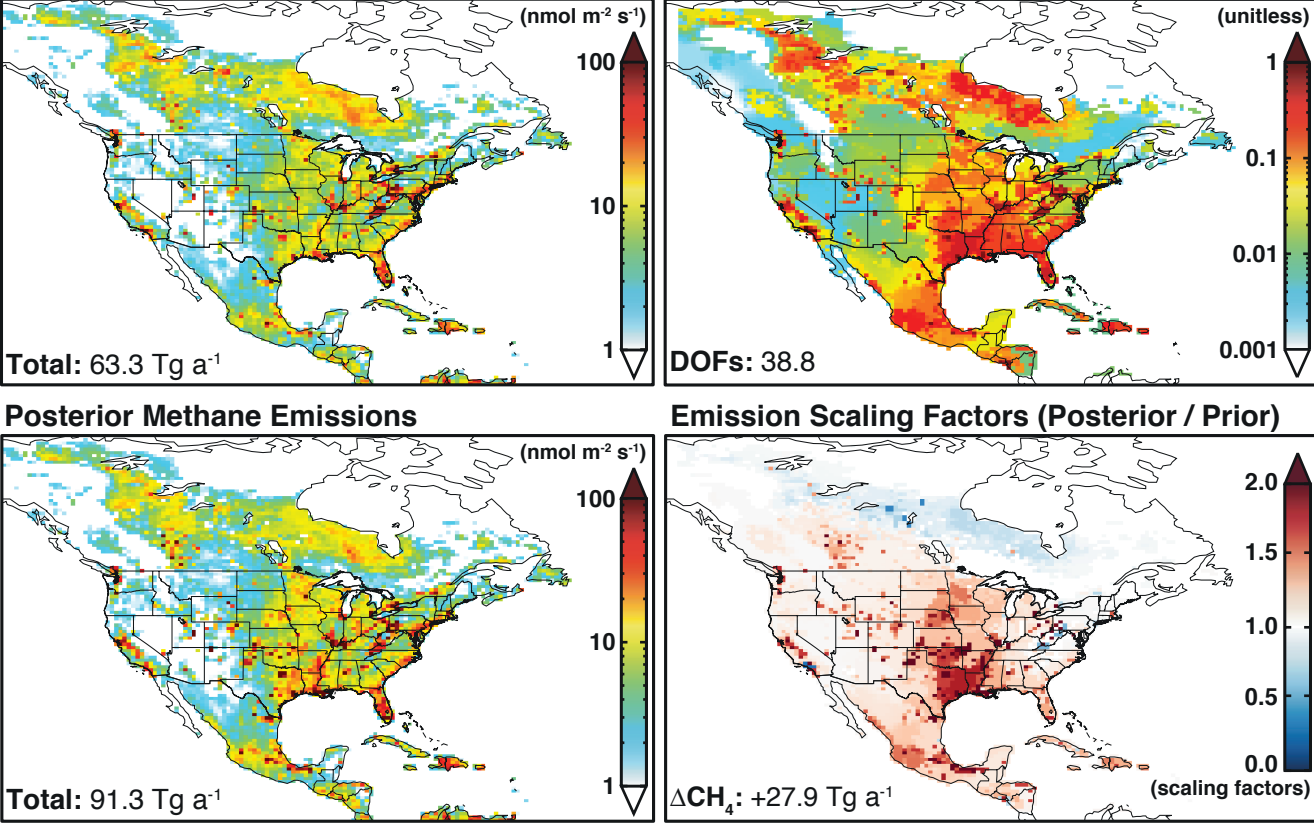

Emission Scaling Factors (Posterior / Prior)

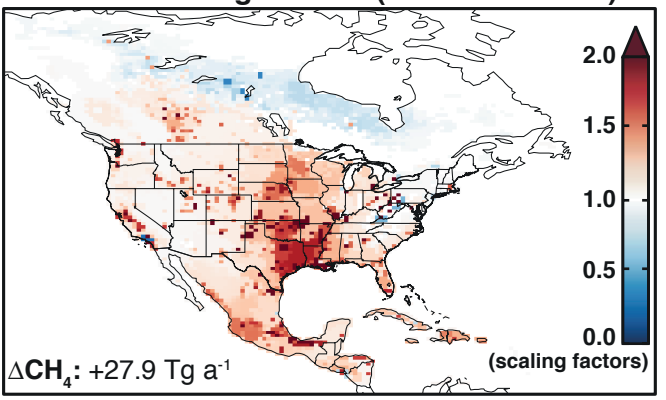

Figure 4. Methane emissions in North America in 2009-2011. The left panels show the prior and posterior emissions and the bottom right panel shows the scaling factors. The top right panel shows the diagonal elements of the averaging kernel matrix for the methane emission inversion. The degrees of freedom for signal (DOFS) is the trace of the averaging kernel matrix.

correct (aseasonal except for wetlands and open fires; see Appendix).

Following Turner and Jacob (2015), the dimension of the emissions state vector for the nested North American inversion is optimally reduced from the native $1 / 2^{\circ} \times 2 / 3^{\circ}$ resolution $(n=7366)$ in order to (1) improve the observational constraints on individual state vector elements and (2) enable an analytical inversion with full error characterization. This is done by aggregating similar state vector elements with a Gaussian mixture model (Bishop, 2007). We find that an optimal reduction with negligibly small aggregation error can be achieved using 369 radial basis functions (RBFs) with Gaussian kernels. The RBFs are constructed from estimation of the factors driving error correlations between the nativeresolution state vector elements including spatial proximity, correction from one iteration of an adjoint-based inversion at $1 / 2^{\circ} \times 2 / 3^{\circ}$ resolution, and prior source type distributions. Including the correction from the adjoint-based inversion allows us to account for sources not included in the prior. Each $1 / 2^{\circ} \times 2 / 3^{\circ}$ native-resolution grid square is projected onto an aggregated state vector using the RBFs. This preserves native resolution where needed (in particular for large point sources) and aggregates large regions where emissions are uniformly small.

Our optimal estimate of North American emissions was obtained by analytical solution to Eq. (2) (cf. Rodgers, 2000), using the Jacobian matrix $\mathbf{K}$ constructed column by column for the aggregated state vector. This analytical approach pro- vides the posterior covariance matrix $\hat{\mathbf{S}}$ and averaging kernel matrix $\mathbf{A}$ as part of the solution and thus fully characterizes the errors and information content of the inversion results.

The observational error covariance matrix is assumed diagonal with terms specified as the larger of the residual error variance and the retrieval error variance, same as for the global inversion. The prior error covariance matrix is assumed diagonal because the radial basis functions are designed to capture spatial correlations in the emissions. We assume $100 \%$ error on emissions at the native $1 / 2^{\circ} \times 2 / 3^{\circ}$ resolution. For RBFs encompassing larger spatial regions, we assume that the error is reduced following the central limit theorem:

$$
S_{\mathrm{a},\{i, i\}}=\frac{s_{\mathrm{a}}}{\sqrt{\sum_{j} w_{i, j}}},
$$

where $S_{\mathrm{a},\{i, i\}}$ is the $i$ th diagonal of $\mathbf{S}_{\mathrm{a}}, s_{\mathrm{a}}$ is the prior uncertainty at the native resolution $(100 \%)$, and the summation is for the weights of the $i$ th $\mathrm{RBF}$ over all $1 / 2^{\circ} \times 2 / 3^{\circ}$ grid squares (index $j$ ). This error reduction assumes that the errors on the native-resolution grid cells are independent and identically distributed, which may be overly optimistic. We examined the sensitivity to this assumption by conducting an alternate inversion with a relative error of $30 \%$ for all state vector elements, similar to the approach taken by Wecht et al. (2014a) using a hierarchial clustering method for the state vector. 
Figure 4 shows the prior and posterior 2009-2011 emissions. Total posterior emissions in North America (Table 1) are $44 \%$ higher than the prior, with large increases in the southern-central US and weak decreases for the Canadian wetlands. Contiguous US emissions are $52 \mathrm{Tga}^{-1}, 70 \%$ higher than the prior. The broad correction patterns are consistent with the coarse global results in Fig. 3 that used a completely different inversion method. Our sensitivity inversion assuming $30 \%$ prior error on all state vector elements yields the same North American and contiguous US totals to within $3 \%$.

We evaluated the posterior emissions in a GEOS-Chem simulation over North America by comparison to the independent observations from Table 2 . We find great improvement in the ability of the model to reproduce these observations, as illustrated by the scatterplots of Fig. 5. The reducedmajor-axis (RMA) regression slopes improve from 0.72 to 1.03 for the NOAA/ESRL tall tower network, from 0.75 to 0.94 for the NOAA/ESRL aircraft profiles, and from 0.67 to 1.01 for the NOAA surface flasks.

Another independent evaluation of our posterior emissions is the estimate for California. California's methane emissions have been extensively studied with aircraft and ground-based observations over the past few years in order to address statewide greenhouse gas regulation targets (Zhao et al., 2009; Wunch et al., 2009; Hsu et al., 2010; Peischl et al., 2012; Wennberg et al., 2012; Jeong et al., 2012, 2013; Peischl et al., 2013; Santoni et al., 2015; Wecht et al., 2014b). Figure 6 shows that our posterior emissions are $20 \%$ higher than the EDGARv4.2 prior inventory for the state of California and $50 \%$ lower for the Southern California Air Basin (SoCAB). Other studies constrained with dense aircraft and ground-based observations are consistent with ours. Our estimate for SoCAB could be biased low due to an underestimate of local $\mathrm{CO}_{2}$ in the GOSAT retrieval (see Sect. 2). Wecht et al. (2014b) previously found that GOSAT observations were not sufficiently dense to constrain methane emissions in California. However, they only used a 2-month record and tried to constrain emissions at $1 / 2^{\circ} \times 2 / 3^{\circ}$ resolution, incurring large smoothing error. By using a longer time record and an optimally defined state vector, we achieve much better success.

Figure 4 (top right panel) shows the averaging kernel sensitivities for the North American methane emission inversion, defined as the diagonals of the averaging kernel matrix. The inversion has 39 degrees of freedom for signal (DOFs), meaning that we can exactly constrain 39 pieces of information in the distribution of methane emissions. This information is spread over the continent and mixed with prior constraints as described by the averaging kernel matrix. We can use the averaging kernel sensitivities in Fig. 4 to determine which regions are most responsive to the inversion. These include California, the Canadian wetlands, and the southeastern and central US. Large isolated point sources such as the US Four Corners (a large source of coalbed methane at

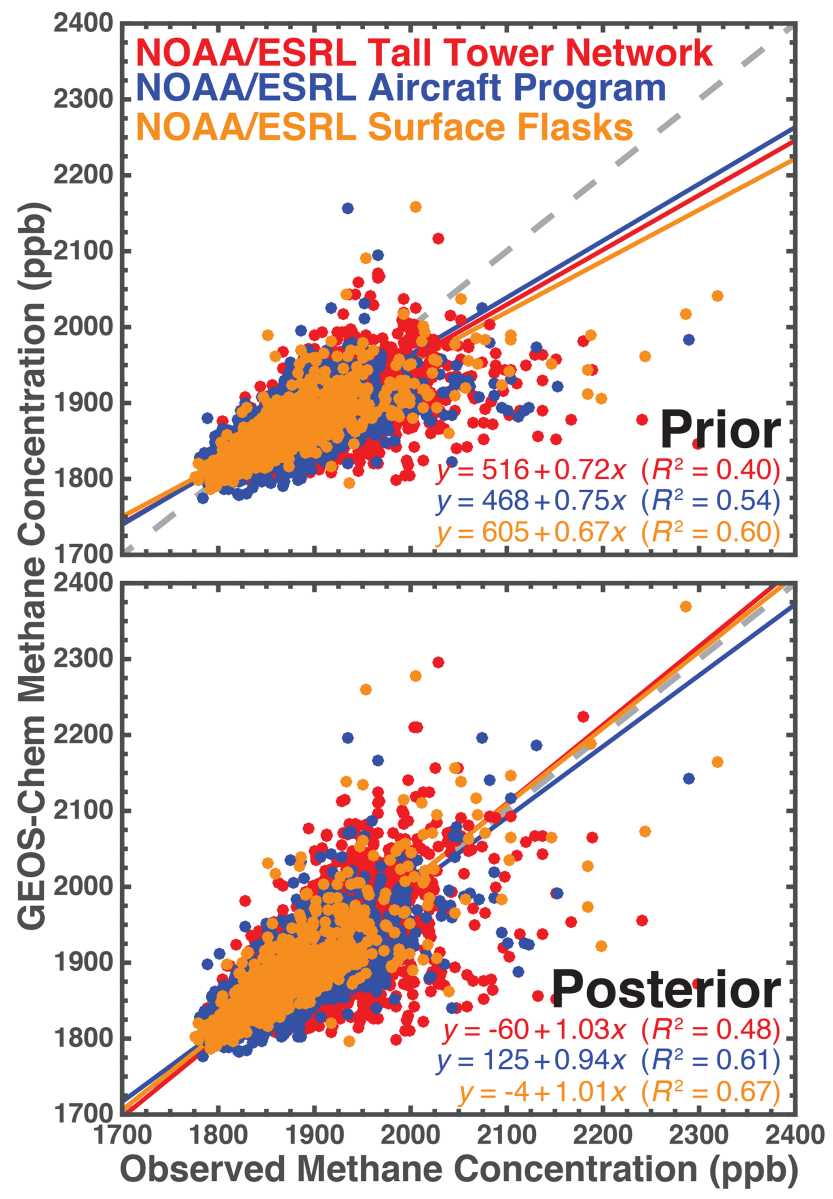

Figure 5. Evaluation of the GOSAT inversion of methane emissions for North America with independent data sets. The scatterplots show comparisons of GEOS-Chem $\left(1 / 2^{\circ} \times 2 / 3^{\circ}\right.$ resolution $)$ methane concentrations with observations from the NOAA/ESRL tall tower network (red), NOAA/ESRL aircraft program (blue), and the NOAA/ESRL surface flask network (orange), using prior emissions (top) and posterior emissions (bottom). The 1:1 lines (dashed) and reduced-major-axis (RMA, solid) linear regressions are also shown. RMA regression parameters are shown inset and correspond to the statistics of Table 2 .

the corner of Arizona, New Mexico, Colorado, and Utah) are also strongly sensitive to the inversion.

We see from Fig. 4 that the prior underestimate of North American methane emissions is largely due to the central US, the Canadian Oil Sands, central Mexico, California, and Florida. Various large point sources such as the US Four Corners also contribute. We also find regions where the prior is too high, including the Hudson Bay Lowlands, SoCAB, and parts of Appalachia. This suggests that oil/gas and livestock emissions are higher than given in EDGARv4.2, while coal emissions are lower. The overestimate in SoCAB is likely because EDGARv4.2 uses urban and rural population as a spatial proxy for landfills and waste water (Wunch et al., 2009). 


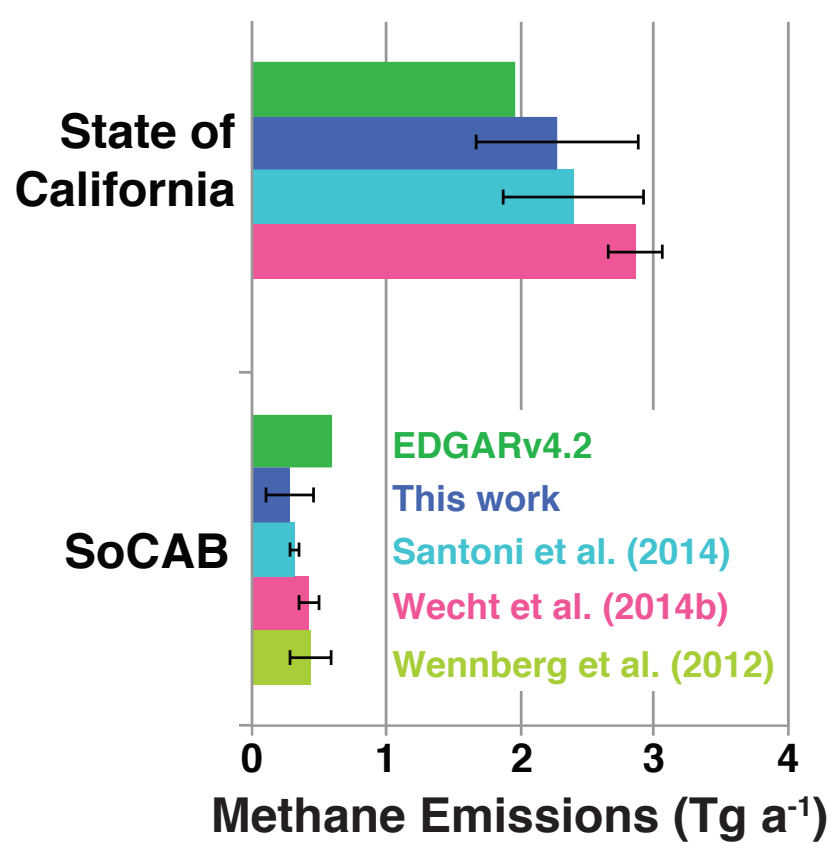

Figure 6. Methane emissions for the state of California (top) and for the Southern California Air Basin (SoCAB; bottom). Our posterior emissions (this work) are compared to prior emissions (EDGARv4.2) and to previous inverse estimates constrained by surface and aircraft observations. SoCAB is defined following Wennberg et al. (2012) as the domain $33.5-34.5^{\circ} \mathrm{N}, 117-119^{\circ} \mathrm{W}$.

The underestimate in Florida is most likely due to wetland sources.

As with the global inversion, we infer the contributions from different methane source types by assuming that the prior inventory correctly attributes the source types in a given $1 / 2^{\circ} \times 2 / 3^{\circ}$ grid cell. Again, this does not assume that the prior distribution is correct, only that the identification of locally dominant sources is correct. Results are shown in Fig. 7. We see that the increase relative to the prior is mainly driven by anthropogenic sources. This can be compared to the US EPA anthropogenic inventory (EPA, 2014), which is based on more detailed bottom-up information than EDGARv4.2 but is only available as a national total. We find an anthropogenic source for the contiguous US of $40.2-42.7 \mathrm{Tg} \mathrm{a}^{-1}$, as compared to $27.0 \mathrm{Tg} \mathrm{a}^{-1}$ in the US EPA inventory. The largest differences are for the oil/gas and livestock sectors. Depending on the assumptions made regarding the prior error, oil/gas emissions from our inversion are 13-74\% higher than the EPA estimate and contribute $17-26 \%$ of contiguous US methane emissions. Livestock emissions are 36-85\% higher than the EPA estimate and contribute $24-33 \%$ of contiguous US methane emissions. Waste and coal emissions are also higher in our posterior estimate than in the EPA inventory.

\section{Comparison to previous inverse studies}

Several past inverse analyses have estimated methane emissions in the contiguous US with differing conclusions, in particular the work of Miller et al. (2013) and Wecht et al. (2014a). Miller et al. (2013) used in situ observations for 2007-2008 from ground stations and aircraft. They found the EPA inventory to be underestimated by a factor of 1.5 nationally, with the largest underestimates in fossil fuel source regions. This is in contrast to Wecht et al. (2014a), who used July-August 2004 observations from SCIAMACHY. They found that the EPA inventory was underestimated by only $10 \%$, with the major discrepancy being livestock emissions underestimated by $40 \%$.

Our continental-scale inversion yields a total US methane emission of $52.4 \mathrm{Tga}^{-1}$ and an anthropogenic source of $42.8 \mathrm{Tg} \mathrm{a}^{-1}$. The general spatial pattern of the posterior emissions is similar to those of Miller et al. (2013) and Wecht et al. (2014a), but the total methane emissions found here are more similar to Miller et al. (2013), who found US total and anthropogenic emissions of 47.2 and $44.5 \mathrm{Tg} \mathrm{a}^{-1}$. The corresponding values obtained by Wecht et al. (2014a) are 38.8 and $30.0 \mathrm{Tg} \mathrm{a}^{-1}$, significantly lower.

Our work finds a larger natural methane source in the contiguous US than Miller et al. (2013), who used a fixed prior wetland source of $2.7 \mathrm{Tg} \mathrm{a}^{-1}$ that was subtracted from the measurements. Our prior and posterior emissions are 5.9 and 9.0-10.1 $\mathrm{Tg} \mathrm{a}^{-1}$, respectively, mostly located in Louisiana and Florida and more consistent with Wecht et al. (2014a). Quantifying the wetlands source is important because it subtracts from the anthropogenic source estimate inferred from the inversion. In particular, our anthropogenic source of methane in the contiguous US would be larger than that of Miller et al. (2013) if we had not corrected for the larger wetland source.

Kort et al. (2014) found the Four Corners to be the largest single methane source in the continental US $\left(0.59 \mathrm{Tg} \mathrm{a}^{-1}\right)$ on the basis of SCIAMACHY observations and TCCON observations, with a magnitude 3.5 times larger than EDGARv4.2 and 1.8 times larger than reported by the US EPA Greenhouse Gas Reporting Program (EPA, 2014). This is in contrast to Miller et al. (2013), who found the US Four Corners to be overestimated in EDGARv4.2 but only had weak constraints for that region. Our work finds methane emissions from the US Four Corners to be $0.45-1.39 \mathrm{Tg} \mathrm{a}^{-1}$ and 3-9 times larger than in the EDGARv4.2 inventory, consistent with the finding of Kort et al. (2014).

Miller et al. (2013) attributed most of the underestimate in the US EPA methane inventory to fossil fuel, while Wecht et al. (2014a) attributed it to livestock. We find in our inversion that the source attribution is highly dependent on the specification of the prior error covariance matrix, as shown in Fig. 7. Our standard inversion that adjusts the prior error for the RBF weights (Eq. 3) attributes $31 \%$ of US anthropogenic emissions to oil/gas and $29 \%$ to livestock, so that 


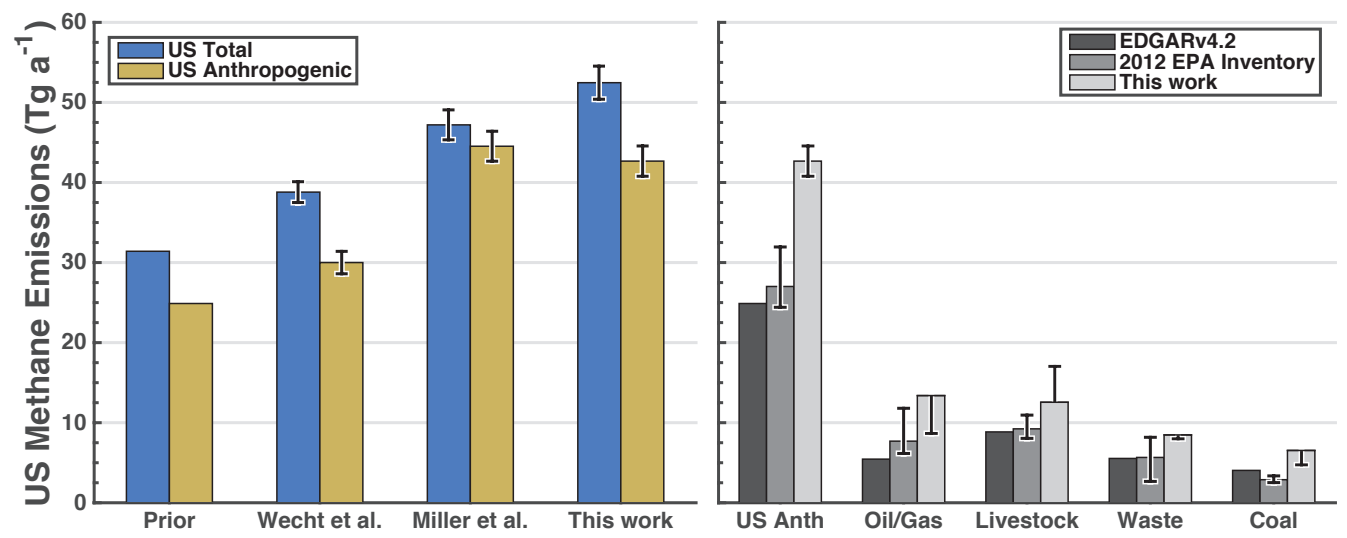

Figure 7. Methane emissions in the contiguous US. The left panel shows our best estimates of total and anthropogenic emissions (this work) compared to the prior (EDGARv4.2 for anthropogenic sources, Pickett-Heaps et al. (2011) for wetlands) and the previous inverse studies of Wecht et al. (2014a) and Miller et al. (2013). The right panel partitions US anthropogenic emissions by source types and compares our results (this work) to EDGARv4.2 and to the 2012 EPA inventory (EPA, 2014). Error bars on sectoral emissions for our results are defined by the sensitivity inversion with $30 \%$ prior uncertainty for all state vector elements.

most of the EPA underestimate is for oil/gas. However, an inversion without this prior error adjustment (error bars in Fig. 7) finds the underestimate to be mainly from livestock. This is because the RBFs associated with livestock emissions tend to cover larger areas of correlated emissions than the point sources associated with oil/gas. An inversion with equal error weighting for different state vector elements will tend to favor correction of the larger elements associated with livestock. With current prior knowledge it is thus difficult to conclusively attribute the US EPA underestimate to oil/gas or livestock emissions. This limitation could be addressed by a better prior knowledge of the spatial distribution of source types or by the use of correlative information (e.g., observations of ethane originating from oil/gas) in the inversion.

\section{Conclusions}

We used 31 months of GOSAT satellite observations of methane columns (June 2009-December 2011) to constrain methane emissions at high spatial resolution in North America with an inversion based on the GEOS-Chem chemical transport model. We first conducted a global adjoint-based inversion at $4^{\circ} \times 5^{\circ}$ resolution and used the resulting optimized fluxes as dynamic boundary conditions for a nested inversion with resolution up to $50 \mathrm{~km} \times 50 \mathrm{~km}$ over North America.

We began by evaluating the GOSAT observations with a large ensemble of aircraft and surface data (HIPPO, NOAA/ESRL surface flasks, NOAA/ESRL aircraft, TCCON), using GEOS-Chem as an intercomparison platform. This revealed a high-latitude bias in the GEOS-Chem polar stratospheric methane (or possibly in the GOSAT data) that we corrected for the purpose of the inversion. The aircraft and surface data were subsequently used as an independent check of our inversion results.

Our global GOSAT inversion finds a total methane source of $539 \mathrm{Tg} \mathrm{a}^{-1}$ with $39 \%$ from wetlands, $22 \%$ from livestock, $12 \%$ from oil/gas, $12 \%$ from waste, $8 \%$ from rice, and $6 \%$ from coal. Comparison to the EDGARv4.2 inventory used as a prior for the inversion indicates that Chinese coal emissions are a factor of 2 too large, consistent with the findings of Bergamaschi et al. (2013) and Bruhwiler et al. (2014). We find large regional corrections to the EDGARv4.2 inventory including a $10 \mathrm{Tg} \mathrm{a}^{-1}$ increase in the wetland emissions in South America and a $10 \mathrm{Tg} \mathrm{a}^{-1}$ increase in rice emissions in Southeast Asia.

Our North American continental-scale inversion used an emission state vector optimally defined with radial basis functions (RBFs) to enable analytical inversion with full error characterization while minimizing aggregation error (Turner and Jacob, 2015). In this manner we could resolve large point sources at a resolution of up to $50 \mathrm{~km} \times 50 \mathrm{~km}$ while aggregating regions with weak emissions. Our posterior anthropogenic methane source for the contiguous US is 40.2-42.7 $\mathrm{Tg} \mathrm{a}^{-1}$, compared to $25.0 \mathrm{Tg} \mathrm{a}^{-1}$ in EDGARv4.2 and $27.9 \mathrm{Tg} \mathrm{a}^{-1}$ in the US EPA national inventory. Differences are particularly large in the southern-central US. Our posterior inventory is more consistent with independent surface and aircraft data and with previous studies in California. On the basis of prior emission patterns, we attribute $22-31 \%$ of US anthropogenic methane emissions to oil/gas, 29-44\% to livestock, $20 \%$ to waste, and $11-15 \%$ to coal. There is in addition a $9.0-10.1 \mathrm{Tg} \mathrm{a}^{-1}$ wetlands source.

Our work confirms previous studies pointing to a large underestimate in the US EPA methane inventory. This underestimate is attributable to oil/gas and livestock emissions, but quantitative separation between the two is difficult because 
of spatial overlap and limitations of the observing system and prior estimates. We find that either oil/gas or livestock emissions dominate the correction to prior emissions depending on assumptions regarding prior errors. This limitation could be addressed in the future through better specification of the prior source distribution using high-resolution information on activity rates, and through the use of correlated variables in the inversion. 
Appendix A: GEOS-Chem description and evaluation with independent data

We use the v9-01-02 GEOS-Chem methane simulation (http://acmg.seas.harvard.edu/geos/index.html; Wecht et al., 2014a) driven by Goddard Earth Observing System (GEOS-5) assimilated meteorological data for 2009-2011 from the NASA Modeling and Assimilation Office (GMAO). The GEOS-5 data have a native horizontal resolution of $1 / 2^{\circ} \times 2 / 3^{\circ}$ with 72 pressure levels and $6 \mathrm{~h}$ temporal resolution ( $3 \mathrm{~h}$ for surface variables and mixing depths). The results presented here are from nested simulations at the native $1 / 2^{\circ} \times 2 / 3^{\circ}$ resolution over North America $\left(10-70^{\circ} \mathrm{N}, 40\right.$ $\left.140^{\circ} \mathrm{W}\right)$ and global simulations at $4^{\circ} \times 5^{\circ}$ resolution. GEOSChem has been extensively evaluated in the past (e.g., Park et al., 2004, 2006; L. Zhang et al., 2011, 2012; van Donkelaar et al., 2012) including three recent studies that used GEOS-5 meteorology over North America (Y. Zhang et al., 2012; Ellis et al., 2013; Zhang et al., 2014). These show a good simulation of regional transport with no apparent biases. Dynamic boundary conditions for the nested simulations are obtained from the global simulations. Methane loss is mainly by reaction with the $\mathrm{OH}$ radical. We use a 3-D archive of monthly average $\mathrm{OH}$ concentrations from Park et al. (2004). The resulting atmospheric lifetime of methane is 8.9 years, consistent with the observational constraint of $9.1 \pm 0.9$ years (Prather et al., 2012).

Prior 2009-2011 emissions for the GEOS-Chem methane simulation are from the EDGARv4.2 anthropogenic methane inventory (European Commission, 2011), the wetland model from Kaplan (2002) as implemented by Pickett-Heaps et al. (2011), the GFED3 biomass burning inventory (van der Werf et al., 2010), a termite inventory and soil absorption from Fung et al. (1991), and a biofuel inventory from Yevich and Logan (2003). Wetlands emissions vary with local temperature, inundation, and snow cover. Open fire emissions are specified with $8 \mathrm{~h}$ temporal resolution. Other emissions are assumed aseasonal. Table 1 lists global, North American, and contiguous US emissions. Figures A1 and A2 show the spatial distributions of the global and North American prior emissions for the five largest source types.

We evaluated GEOS-Chem with surface-based (NOAA/ESRL, TCCON), tower (NOAA/ESRL), and aircraft (HIPPO, NOAA/ESRL) observations of methane concentrations for 2009-2011, both as indirect validation of the GOSAT data and as an independent check on our inversion results. See the main text for references for these observations. We convolve GEOS-Chem with the TCCON averaging kernels and priors before comparison with TCCON observations. Figure A3 uses observations from the NOAA cooperative flask network and from the HIPPO data across the Pacific to evaluate the global burden and latitudinal gradient in GEOS-Chem. Figure A4 uses observations from the NOAA/ESRL Global Greenhouse Gas Reference Network and the TCCON column network for a more specific evaluation of the model over North America. Figure A5 shows corresponding scatterplots and Table 2 gives summary statistics. Discussion of the results is given in the text. 


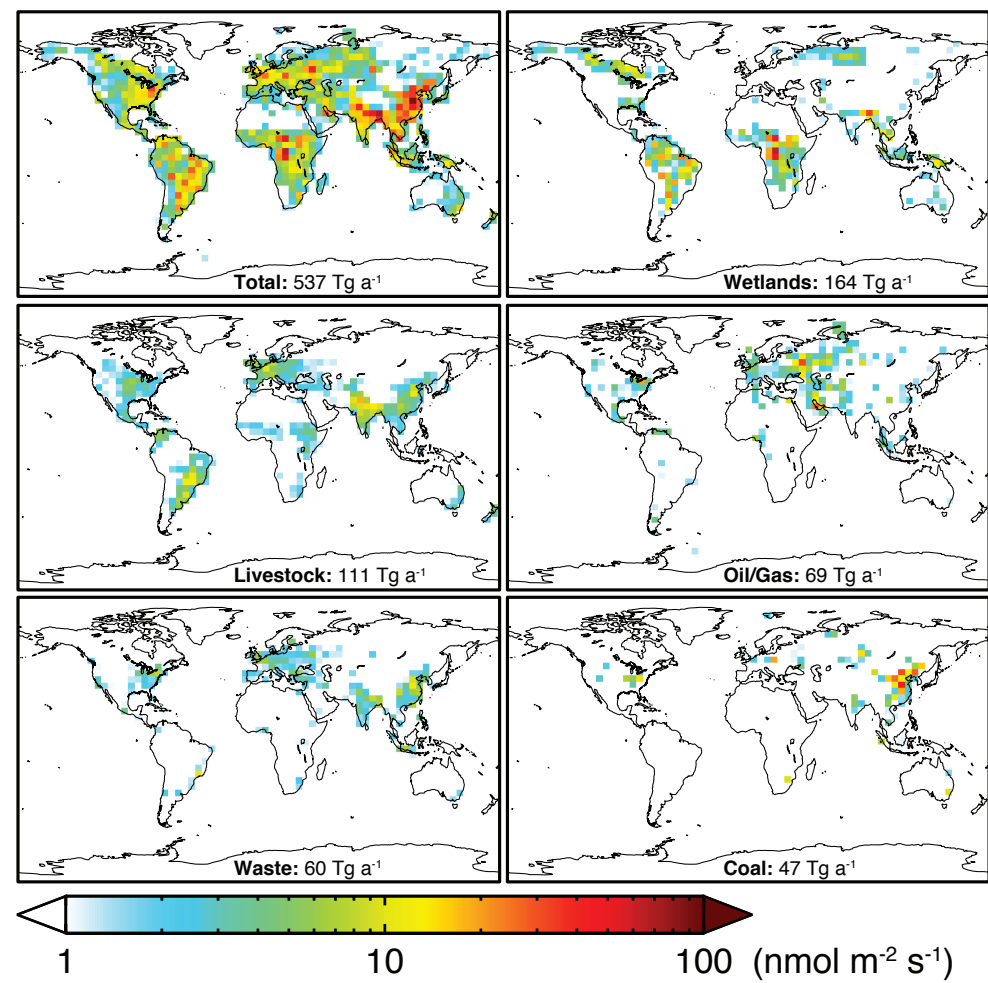

Figure A1. Prior 2009-2011 methane emissions used in the GEOS-Chem global simulation at $4^{\circ} \times 5^{\circ}$ resolution, and contributions from the top five sources.

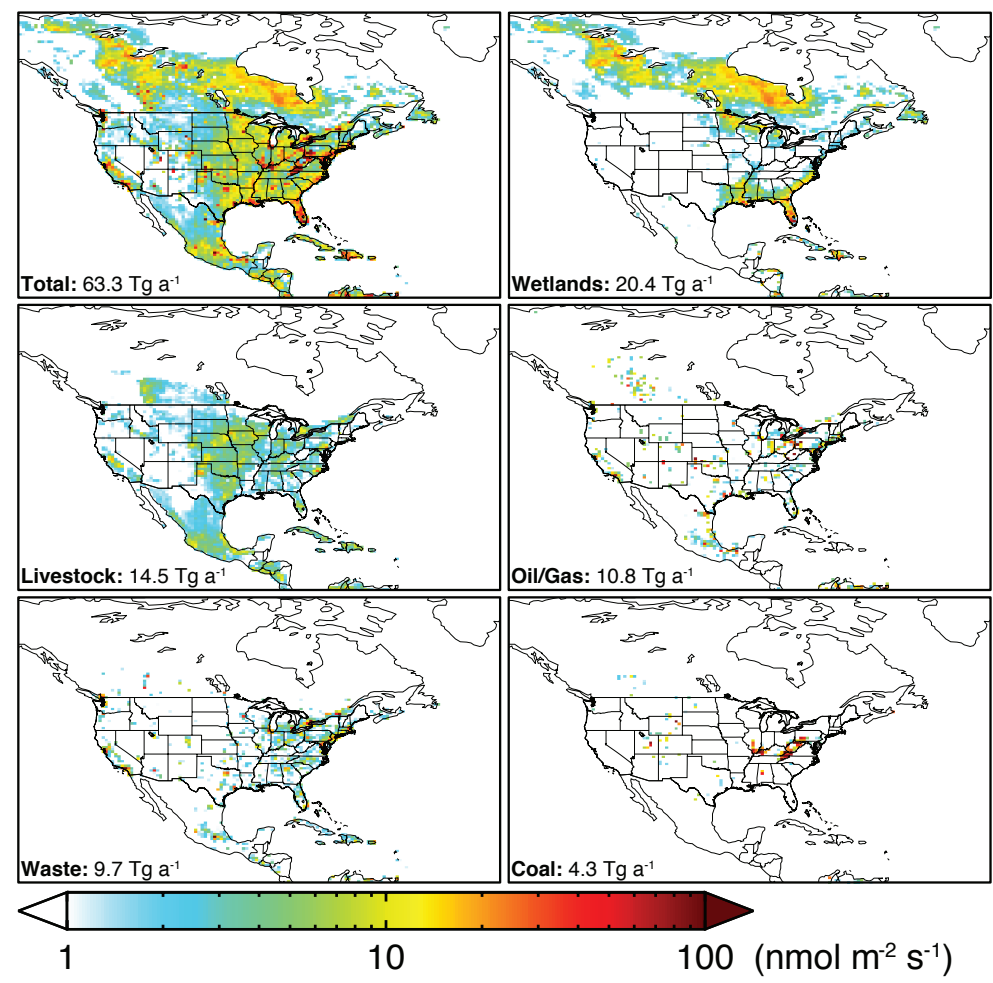

Figure A2. Same as Fig. A1 but for North America with $1 / 2^{\circ} \times 2 / 3^{\circ}$ resolution. 


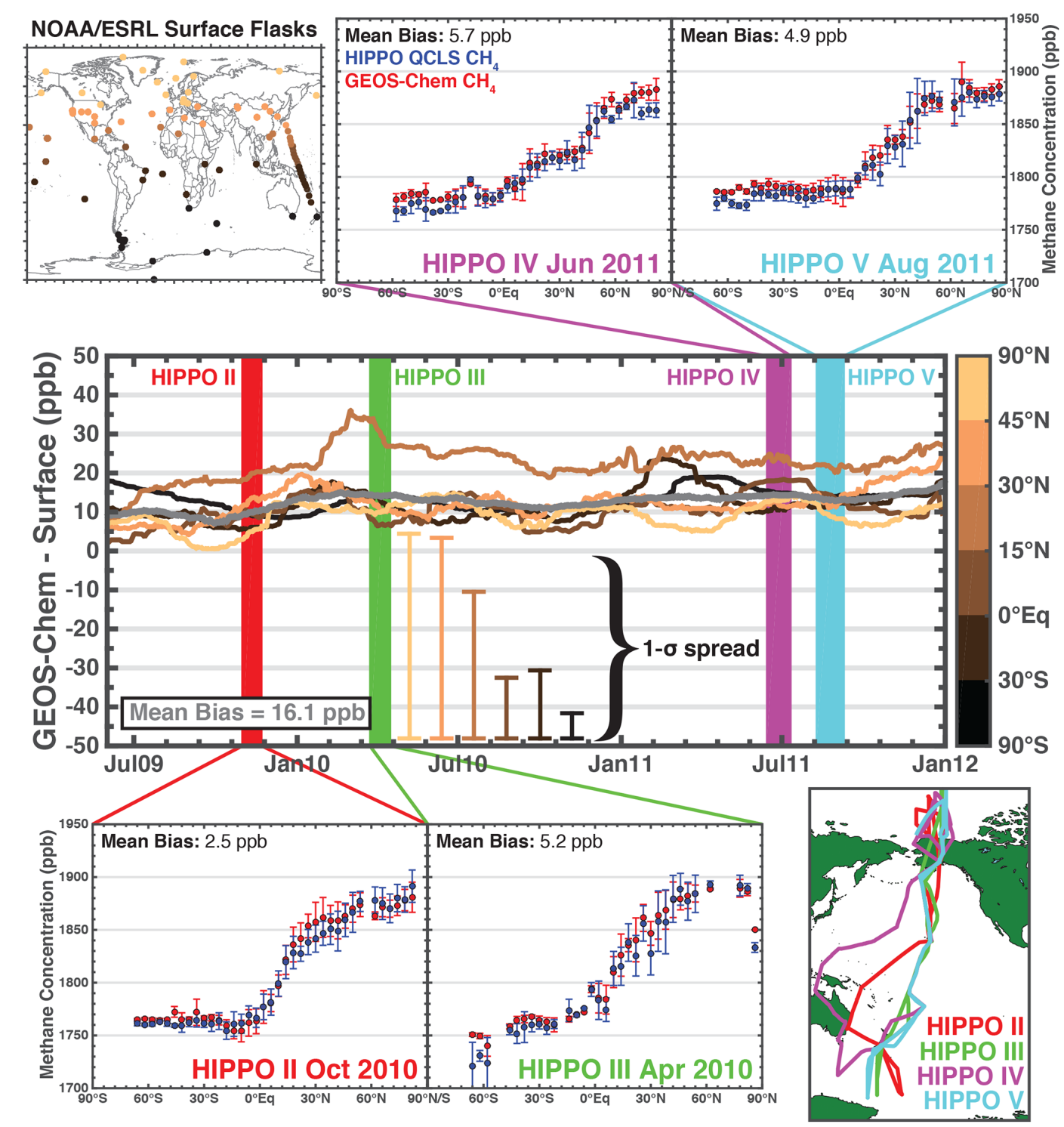

Figure A3. Global evaluation of the GEOS-Chem methane simulation at $4^{\circ} \times 5^{\circ}$ resolution (using prior emissions) with observations from the NOAA/ESRL surface flask network (top left panel colored by latitude) and HIPPO aircraft deployments. The central panel shows 3 month running medians for 2009-2011 of the difference between GEOS-Chem and the flask data in different latitudinal bands. The gray line is for all of the observations. Error bars for the running medians are offset from the lines for clarity. Latitudinal profiles across the Pacific for the four HIPPO deployments over the period are also shown: in those panels the symbols represent the pressure-weighted tropospheric average concentrations and the vertical bars are the standard deviation. Stratospheric air is excluded based on an ozone-CO concentration ratio larger than 1.25 (Hudman et al., 2007). Bottom right panel shows the HIPPO flight tracks. 

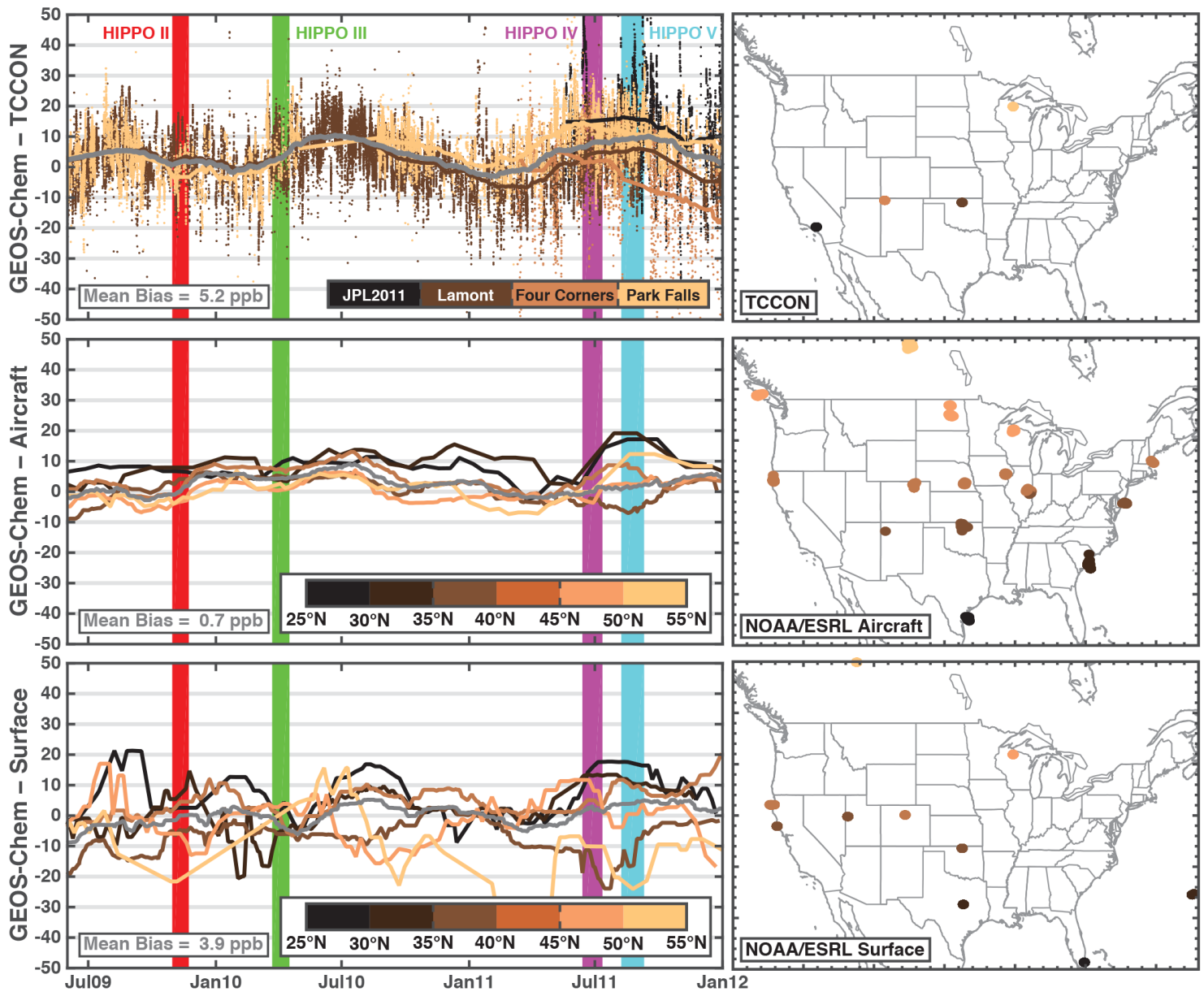

Figure A4. North American evaluation of the GEOS-Chem methane simulation at $4^{\circ} \times 5^{\circ}$ resolution (using prior emissions) with TCCON (top), NOAA/ESRL aircraft program (middle), and NOAA/ESRL surface flask network (bottom) observations over North America. Left panels show 3-month running medians for 2009-2011 of the difference between GEOS-Chem and the observations in different latitudinal bands and for all the data (gray line). Right panels show the location of the observations. All values are in ppb. 


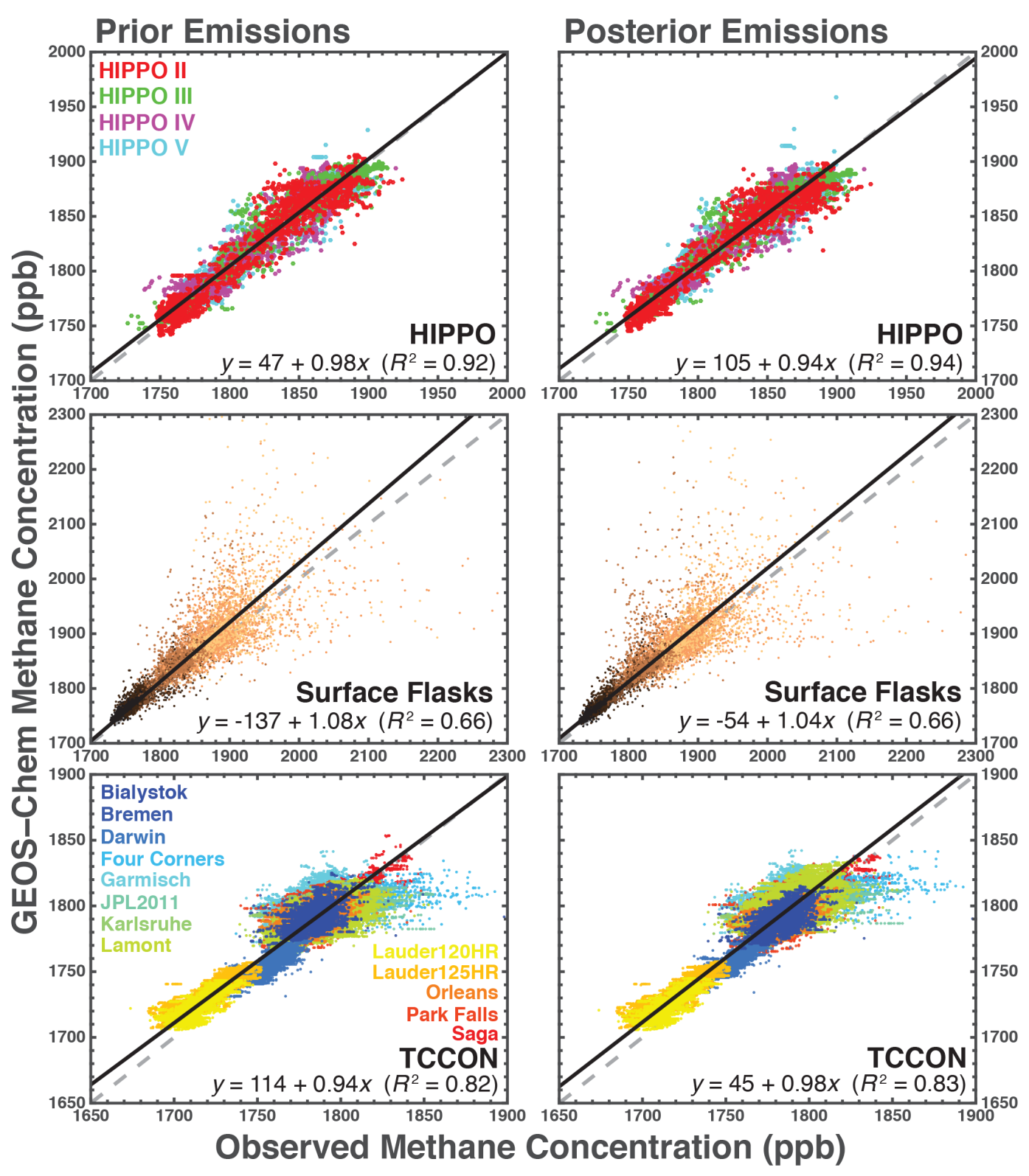

Figure A5. Scatterplot comparison of GEOS-Chem at $4^{\circ} \times 5^{\circ}$ resolution to independent observations. Left column uses prior emissions and right column uses posterior emissions. Individual points show comparisons for individual observations, averaged over the GEOS-Chem grid resolution in the case of the aircraft data. The 1:1 (dashed) and reduced-major-axis (RMA, solid) regression lines are shown. Summary statistics are also given in Table 2. Different colors correspond to different sites (TCCON), latitudinal bands (flasks), and deployments (HIPPO) shown in Fig. A3. 
Acknowledgements. This work was supported by the NASA Carbon Monitoring System and a Department of Energy (DOE) Computational Science Graduate Fellowship (CSGF) to A. J. Turner. We also thank the Harvard SEAS Academic Computing center for access to computing resources. Special thanks to S. C. Wofsy for providing HIPPO aircraft data, and J. B. Miller and M. Parker for providing NOAA/ESRL Global Greenhouse Gas Reference Network data. We thank M. L. Fischer and the CALGEM team at LBNL for their contributions to data collection at tower sites in central California as supported by the California Energy Commission's Natural Gas Program through a grant to the US Department of Energy under contract no. DE-AC02-05CH11231. Part of this work was carried out at the Jet Propulsion Laboratory, California Institute of Technology, under a contract with NASA. R. Parker and $\mathrm{H}$. Boesch acknowledge funding from the UK National Centre for Earth Observation (NCEO) and the ESA Climate Change Initiative (ESA GHG-CCI). TCCON data at Park Falls, Lamont, and JPL is funded by NASA grants NNX11AG01G, NAG5-12247 and NNG05-GD07G, and the NASA Orbiting Carbon Observatory Program. We are grateful to the DOE ARM program for technical support in Lamont and J. Ayers for technical support in Park Falls. TCCON data from Bialystok and Bremen is funded by the EU projects InGOS and ICOS-INWIRE, and by the Senate of Bremen. TCCON data from Darwin is funded by NASA grants NAG5-12247 and NNG05-GD07G and the Australian Research Council, DP0879468 and LP0562346. We are grateful to the DOE ARM program for technical support in Darwin. Garmisch TCCON work has been performed as part of the ESA GHG-cci project via subcontract with the University of Bremen. In addition, we acknowledge funding by the EC within the INGOS project. From 2004 to 2011 the Lauder TCCON program was funded by the New Zealand Foundation of Research Science and Technology contracts CO1X0204, CO1X0703 and CO1X0406. Since 2011, the program has been funded by NIWA's Atmosphere Research Programme 3 (2011/13 Statement of Corporate Intent). M. K. Dubey thanks LANL-LDRD for funding 20110081DR for monitoring at Four Corners. We thank B. Henderson (LANL) for help with retrievals at Four Corners. A part of work at JAXA was supported by the Environment Research and Technology Development Fund (A-1102) of the Ministry of the Environment, Japan. Observations collected in the Southern Great plains were supported by the Office of Biological and Environmental Research of the US Department of Energy under contract no. DE-AC02-05CH11231 as part of the Atmospheric Radiation Measurement Program (ARM), ARM Aerial Facility, and Terrestrial Ecosystem Science Program. HIPPO aircraft data are available at http://hippo.ornl.gov, TCCON data are available at http://tccon.ornl.gov, and NOAA/ESRL Global Greenhouse Gas Reference Network data are available at http://www.esrl.noaa.gov/gmd/ccgg/flask.php.

Edited by: R. Harley

\section{References}

Alexe, M., Bergamaschi, P., Segers, A., Detmers, R., Butz, A., Hasekamp, O., Guerlet, S., Parker, R., Boesch, H., Frankenberg, C., Scheepmaker, R. A., Dlugokencky, E., Sweeney, C., Wofsy, S. C., and Kort, E. A.: Inverse modelling of $\mathrm{CH}_{4}$ emissions for 2010-2011 using different satellite retrieval products from GOSAT and SCIAMACHY, Atmos. Chem. Phys., 15, 113-133, doi:10.5194/acp-15-113-2015, 2015.

Andrews, A. E., Kofler, J. D., Trudeau, M. E., Williams, J. C., Neff, D. H., Masarie, K. A., Chao, D. Y., Kitzis, D. R., Novelli, P. C., Zhao, C. L., Dlugokencky, E. J., Lang, P. M., Crotwell, M. J., Fischer, M. L., Parker, M. J., Lee, J. T., Baumann, D. D., Desai, A. R., Stanier, C. O., De Wekker, S. F. J., Wolfe, D. E., Munger, J. W., and Tans, P. P.: $\mathrm{CO}_{2}, \mathrm{CO}$, and $\mathrm{CH}_{4}$ measurements from tall towers in the NOAA Earth System Research Laboratory's Global Greenhouse Gas Reference Network: instrumentation, uncertainty analysis, and recommendations for future high-accuracy greenhouse gas monitoring efforts, Atmos. Meas. Tech., 7, 647-687, doi:10.5194/amt-7-647-2014, 2014.

Bergamaschi, P., Frankenberg, C., Meirink, J. F., Krol, M., Dentener, F., Wagner, T., Platt, U., Kaplan, J. O., Körner, S., Heimann, M., Dlugokencky, E. J., and Goede, A.: Satellite chartography of atmospheric methane from SCIAMACHY on board ENVISAT: 2. Evaluation based on inverse model simulations, J. Geophys. Res., 112, D02304, doi:10.1029/2006jd007268, 2007.

Bergamaschi, P., Frankenberg, C., Meirink, J. F., Krol, M., Villani, M. G., Houweling, S., Dentener, F., Dlugokencky, E. J., Miller, J. B., Gatti, L. V., Engel, A., and Levin, I.: Inverse modeling of global and regional $\mathrm{CH}_{4}$ emissions using SCIAMACHY satellite retrievals, J. Geophys. Res., 114, D22301, doi:10.1029/2009jd012287, 2009.

Bergamaschi, P., Houweling, S., Segers, A., Krol, M., Frankenberg, C., Scheepmaker, R. A., Dlugokencky, E., Wofsy, S. C., Kort, E. A., Sweeney, C., Schuck, T., Brenninkmeijer, C., Chen, H., Beck, V., and Gerbig, C.: Atmospheric $\mathrm{CH}_{4}$ in the first decade of the 21st century: iverse modeling analysis using SCIAMACHY satellite retrievals and NOAA surface measurements, J. Geophys. Res.-Atmos., 118, 7350-7369, doi:10.1002/jgrd.50480, 2013.

Biraud, S. C., Torn, M. S., Smith, J. R., Sweeney, C., Riley, W. J., and Tans, P. P.: A multi-year record of airborne $\mathrm{CO}_{2}$ observations in the US Southern Great Plains, Atmos. Meas. Tech., 6, 751763, doi:10.5194/amt-6-751-2013, 2013.

Bishop, C. M.: Pattern Recognition and Machine Learning, 1st Edn., Springer, New York, 2007.

Bruhwiler, L., Dlugokencky, E., Masarie, K., Ishizawa, M., Andrews, A., Miller, J., Sweeney, C., Tans, P., and Worthy, D.: CarbonTracker- $\mathrm{CH}_{4}$ : an assimilation system for estimating emissions of atmospheric methane, Atmos. Chem. Phys., 14, 82698293, doi:10.5194/acp-14-8269-2014, 2014.

Butz, A., Hasekamp, O. P., Frankenberg, C., Vidot, J., and Aben, I.: $\mathrm{CH}_{4}$ retrievals from space-based solar backscatter measurements: performance evaluation against simulated aerosol and cirrus loaded scenes, J. Geophys. Res., 115, D24302, doi:10.1029/2010jd014514, 2010.

Butz, A., Guerlet, S., Hasekamp, O., Schepers, D., Galli, A., Aben, I., Frankenberg, C., Hartmann, J. M., Tran, H., Kuze, A., Keppel-Aleks, G., Toon, G., Wunch, D., Wennberg, P., Deutscher, N., Griffith, D., Macatangay, R., Messerschmidt, J., Notholt, J., and Warneke, T.: Toward accurate $\mathrm{CO}_{2}$ and $\mathrm{CH}_{4}$ observations from GOSAT, Geophys. Res. Lett., 38, L14812, doi:10.1029/2011g1047888, 2011.

Caulton, D. R., Shepson, P. B., Santoro, R. L., Sparks, J. P., Howarth, R. W., Ingraffea, A. R., Cambaliza, M. O., Sweeney, C., 
Karion, A., Davis, K. J., Stirm, B. H., Montzka, S. A., and Miller, B. R.: Toward a better understanding and quantification of methane emissions from shale gas development, P. Natl. Acad. Sci. USA, 111, 6237-6242, doi:10.1073/pnas.1316546111, 2014.

Climate and Clean Air Coalition: 2013-2014 Annual Report, Tech. rep., available at: http://ccacoalition.org/docs/pdf/CCAC_ Annual_Report_2013-2014.pdf, last access: 1 December 2014.

Cressot, C., Chevallier, F., Bousquet, P., Crevoisier, C., Dlugokencky, E. J., Fortems-Cheiney, A., Frankenberg, C., Parker, R., Pison, I., Scheepmaker, R. A., Montzka, S. A., Krummel, P. B., Steele, L. P., and Langenfelds, R. L.: On the consistency between global and regional methane emissions inferred from SCIAMACHY, TANSO-FTS, IASI and surface measurements, Atmos. Chem. Phys., 14, 577-592, doi:10.5194/acp-14-577-2014, 2014.

Deutscher, N. M., Griffith, D. W. T., Bryant, G. W., Wennberg, P. O., Toon, G. C., Washenfelder, R. A., Keppel-Aleks, G., Wunch, D., Yavin, Y., Allen, N. T., Blavier, J.-F., Jiménez, R., Daube, B. C., Bright, A. V., Matross, D. M., Wofsy, S. C., and Park, S.: Total column $\mathrm{CO}_{2}$ measurements at Darwin, Australia - site description and calibration against in situ aircraft profiles, Atmos. Meas. Tech., 3, 947-958, doi:10.5194/amt-3-947-2010, 2010.

Dlugokencky, E. J., Nisbet, E. G., Fisher, R., and Lowry, D.: Global atmospheric methane: budget, changes and dangers, Philos. T. Roy. Soc. A, 369, 2058-2072, doi:10.1098/rsta.2010.0341, 2011.

Ellis, R. A., Jacob, D. J., Sulprizio, M. P., Zhang, L., Holmes, C. D., Schichtel, B. A., Blett, T., Porter, E., Pardo, L. H., and Lynch, J. A.: Present and future nitrogen deposition to national parks in the United States: critical load exceedances, Atmos. Chem. Phys., 13, 9083-9095, doi:10.5194/acp-13-9083-2013, 2013.

EPA, U.: Inventory of U.S. Greenhouse Gas Emissions and Sinks: 1990-2012, Tech. rep., US Environmental Protection Agency, Washington DC, 2014.

European Commission: Emission Database for Global Atmospheric Research (EDGAR), release version 4.2, Tech. rep., Joint Research Centre (JRC)/Netherlands Environmental Assessment Agency (PBL), available at: http://edgar.jrc.ec.europa.eu (last access: 1 December 2014), 2011.

Frankenberg, C., Meirink, J. F., van Weele, M., Platt, U., and Wagner, T.: Assessing methane emissions from global space-borne observations, Science, 308, 1010-1014, doi:10.1126/science.1106644, 2005.

Frankenberg, C., Aben, I., Bergamaschi, P., Dlugokencky, E. J., van Hees, R., Houweling, S., van der Meer, P., Snel, R., and Tol, P.: Global column-averaged methane mixing ratios from 2003 to 2009 as derived from SCIAMACHY: trends and variability, J. Geophys. Res., 116, D04302, doi:10.1029/2010jd014849, 2011.

Fraser, A., Palmer, P. I., Feng, L., Boesch, H., Cogan, A., Parker, R., Dlugokencky, E. J., Fraser, P. J., Krummel, P. B., Langenfelds, R. L., O’Doherty, S., Prinn, R. G., Steele, L. P., van der Schoot, M., and Weiss, R. F.: Estimating regional methane surface fluxes: the relative importance of surface and GOSAT mole fraction measurements, Atmos. Chem. Phys., 13, 5697-5713, doi:10.5194/acp-13-5697-2013, 2013.

Fung, I., John, J., Lerner, J., Matthews, E., Prather, M., Steele, L. P., and Fraser, P. J.: Three-dimensional model synthesis of the global methane cycle, J. Geophys. Res., 96, 13033, doi:10.1029/91jd01247, 1991.
Geibel, M. C., Messerschmidt, J., Gerbig, C., Blumenstock, T., Chen, H., Hase, F., Kolle, O., Lavric, J. V., Notholt, J., Palm, M., Rettinger, M., Schmidt, M., Sussmann, R., Warneke, T., and Feist, D. G.: Calibration of column-averaged $\mathrm{CH}_{4}$ over European TCCON FTS sites with airborne in-situ measurements, Atmos. Chem. Phys., 12, 8763-8775, doi:10.5194/acp-12-87632012, 2012.

Heald, C. L., Jacob, D. J., Jones, D. B. A., Palmer, P. I., Logan, J. A., Streets, D. G., Sachse, G. W., Gille, J. C., Hoffman, R. N., and Nehrkorn, T.: Comparative inverse analysis of satellite (MOPITT) and aircraft (TRACE-P) observations to estimate Asian sources of carbon monoxide, J. Geophys. Res.Atmos., 109, D23306, doi:10.1029/2004jd005185, 2004.

Henze, D. K., Hakami, A., and Seinfeld, J. H.: Development of the adjoint of GEOS-Chem, Atmos. Chem. Phys., 7, 2413-2433, doi:10.5194/acp-7-2413-2007, 2007.

Hsu, Y. K., VanCuren, T., Park, S., Jakober, C., Herner, J., FitzGibbon, M., Blake, D. R., and Parrish, D. D.: Methane emissions inventory verification in southern California, Atmos. Environ., 44, 1-7, doi:10.1016/ J.Atmosenv.2009.10.002, 2010.

Hudman, R. C., Jacob, D. J., Turquety, S., Leibensperger, E. M., Murray, L. T., Wu, S., Gilliland, A. B., Avery, M., Bertram, T. H., Brune, W., Cohen, R. C., Dibb, J. E., Flocke, F. M., Fried, A., Holloway, J., Neuman, J. A., Orville, R., Perring, A., Ren, X., Sachse, G. W., Singh, H. B., Swanson, A., and Wooldridge, P. J.: Surface and lightning sources of nitrogen oxides over the United States: magnitudes, chemical evolution, and outflow, J. Geophys. Res., 112, D12S05, doi:10.1029/2006jd007912, 2007.

IPCC: Climate Change 2013: The Physical Science Basis. Contribution of Working Group I to the Fifth Assessment Report of the Intergovernmental Panel on Climate Change, Tech. rep., Cambridge, United Kingdom and New York, 2013.

Jeong, S., Zhao, C., Andrews, A. E., Bianco, L., Wilczak, J. M., and Fischer, M. L.: Seasonal variation of $\mathrm{CH}_{4}$ emissions from central California, J. Geophys. Res., 117, D11306, doi:10.1029/2011jd016896, 2012.

Jeong, S., Hsu, Y.-K., Andrews, A. E., Bianco, L., Vaca, P., Wilczak, J. M., and Fischer, M. L.: A multitower measurement network estimate of California's methane emissions, J. Geophys. Res.-Atmos., 118, 11339-11351, doi:10.1002/jgrd.50854, 2013.

Kaplan, J. O.: Wetlands at the last glacial maximum: distribution and methane emissions, Geophys. Res. Lett., 29, 3.1-3.4, doi:10.1029/2001g1013366, 2002.

Karion, A., Sweeney, C., Pétron, G., Frost, G., Michael Hardesty, R., Kofler, J., Miller, B. R., Newberger, T., Wolter, S., Banta, R., Brewer, A., Dlugokencky, E., Lang, P., Montzka, S. A., Schnell, R., Tans, P., Trainer, M., Zamora, R., and Conley, S.: Methane emissions estimate from airborne measurements over a western United States natural gas field, Geophys. Res. Lett., 40, 4393-4397, doi:10.1002/grl.50811, 2013.

Katzenstein, A. S., Doezema, L. A., Simpson, I. J., Blake, D. R., and Rowland, F. S.: Extensive regional atmospheric hydrocarbon pollution in the southwestern United States, P. Natl. Acad. Sci. USA, 100, 11975-11979, doi:10.1073/pnas.1635258100, 2003.

Kirschke, S., Bousquet, P., Ciais, P., Saunois, M., Canadell, J. G., Dlugokencky, E. J., Bergamaschi, P., Bergmann, D., Blake, D. R., Bruhwiler, L., Cameron-Smith, P., Castaldi, S., Chevallier, F., Feng, L., Fraser, A., Heimann, M., Hodson, E. L., Houweling, S., Josse, B., Fraser, P. J., Krummel, P. B., Lamarque, J.-F., Langen- 
felds, R. L., Le Quéré, C., Naik, V., O’Doherty, S., Palmer, P. I., Pison, I., Plummer, D., Poulter, B., Prinn, R. G., Rigby, M., Ringeval, B., Santini, M., Schmidt, M., Shindell, D. T., Simpson, I. J., Spahni, R., Steele, L. P., Strode, S. A., Sudo, K., Szopa, S., van der Werf, G. R., Voulgarakis, A., van Weele, M., Weiss, R. F., Williams, J. E., and Zeng, G.: Three decades of global methane sources and sinks, Nat. Geosci., 6, 813-823, doi:10.1038/ngeo1955, 2013.

Kort, E. A., Eluszkiewicz, J., Stephens, B. B., Miller, J. B., Gerbig, C., Nehrkorn, T., Daube, B. C., Kaplan, J. O., Houweling, S., and Wofsy, S. C.: Emissions of $\mathrm{CH}_{4}$ and $\mathrm{N}_{2} \mathrm{O}$ over the United States and Canada based on a receptor-oriented modeling framework and COBRA-NA atmospheric observations, Geophys. Res. Lett., 35, L18808, doi:10.1029/2008g1034031, 2008.

Kort, E. A., Frankenberg, C., Costigan, K. R., Lindenmaier, R., Dubey, M. K., and Wunch, D.: Four corners: the largest US methane anomaly viewed from space, Geophys. Res. Lett., 41, 6898-6903, doi:10.1002/2014g1061503, 2014.

Kuze, A., Suto, H., Nakajima, M., and Hamazaki, T.: Thermal and near infrared sensor for carbon observation Fourier-transform spectrometer on the Greenhouse Gases Observing Satellite for greenhouse gases monitoring, Appl. Optics, 48, 6716-6733, doi:10.1364/A O.48.006716, 2009.

Messerschmidt, J., Geibel, M. C., Blumenstock, T., Chen, H., Deutscher, N. M., Engel, A., Feist, D. G., Gerbig, C., Gisi, M., Hase, F., Katrynski, K., Kolle, O., Lavric, J. V., Notholt, J., Palm, M., Ramonet, M., Rettinger, M., Schmidt, M., Sussmann, R., Toon, G. C., Truong, F., Warneke, T., Wennberg, P. O., Wunch, D., and Xueref-Remy, I.: Calibration of TCCON column-averaged $\mathrm{CO}_{2}$ : the first aircraft campaign over European TCCON sites, Atmos. Chem. Phys., 11, 10765-10777, doi:10.5194/acp-11-10765-2011, 2011.

Messerschmidt, J., Chen, H., Deutscher, N. M., Gerbig, C., Grupe, P., Katrynski, K., Koch, F.-T., Lavric, J. V., Notholt, J., Rödenbeck, C., Ruhe, W., Warneke, T., and Weinzierl, C.: Automated ground-based remote sensing measurements of greenhouse gases at the Bialystok site in comparison with collocated in situ measurements and model data, Atmos. Chem. Phys., 12, 6741-6755, doi:10.5194/acp-12-6741-2012, 2012.

Miller, S. M., Wofsy, S. C., Michalak, A. M., Kort, E. A., Andrews, A. E., Biraud, S. C., Dlugokencky, E. J., Eluszkiewicz, J., Fischer, M. L., Janssens-Maenhout, G., Miller, B. R., Miller, J. B., Montzka, S. A., Nehrkorn, T., and Sweeney, C.: Anthropogenic emissions of methane in the United States, P. Natl. Acad. Sci. USA, 110, 20018-20022, doi:10.1073/pnas.1314392110, 2013.

Monteil, G., Houweling, S., Butz, A., Guerlet, S., Schepers, D., Hasekamp, O., Frankenberg, C., Scheepmaker, R., Aben, I., and Röckmann, T.: Comparison of $\mathrm{CH}_{4}$ inversions based on 15 months of GOSAT and SCIAMACHY observations, J. Geophys. Res.-Atmos., 118, 11807-11823, doi:10.1002/2013jd019760, 2013.

Park, R. J., Jacob, D. J., Field, B. D., Yantosca, R. M., and Chin, M.: Natural and transboundary pollution influences on sulfate-nitrate-ammonium aerosols in the United States: implications for policy, J. Geophys. Res.-Atmos., 109, D15204, doi:10.1029/2003jd004473, 2004.

Park, R. J., Jacob, D. J., Kumar, N., and Yantosca, R. M.: Regional visibility statistics in the United States: Natural and transboundary pollution influences, and implications for the Regional Haze Rule, Atmos. Environ., 40, 5405-5423, doi:10.1016/j.atmosenv.2006.04.059, 2006.

Parker, R., Boesch, H., Cogan, A., Fraser, A., Feng, L., Palmer, P. I., Messerschmidt, J., Deutscher, N., Griffith, D. W. T., Notholt, J., Wennberg, P. O., and Wunch, D.: Methane observations from the Greenhouse Gases Observing SATellite: comparison to groundbased TCCON data and model calculations, Geophys. Res. Lett., 38, L15807, doi:10.1029/2011g1047871, 2011.

Peischl, J., Ryerson, T. B., Holloway, J. S., Trainer, M., Andrews, A. E., Atlas, E. L., Blake, D. R., Daube, B. C., Dlugokencky, E. J., Fischer, M. L., Goldstein, A. H., Guha, A., Karl, T., Kofler, J., Kosciuch, E., Misztal, P. K., Perring, A. E., Pollack, I. B., Santoni, G. W., Schwarz, J. P., Spackman, J. R., Wofsy, S. C., and Parrish, D. D.: Airborne observations of methane emissions from rice cultivation in the Sacramento Valley of California, J. Geophys. Res.-Atmos., 117, D00V25, doi:10.1029/2012jd017994, 2012.

Peischl, J., Ryerson, T. B., Brioude, J., Aikin, K. C., Andrews, A. E., Atlas, E., Blake, D., Daube, B. C., de Gouw, J. A., Dlugokencky, E., Frost, G. J., Gentner, D. R., Gilman, J. B., Goldstein, A. H., Harley, R. A., Holloway, J. S., Kofler, J., Kuster, W. C., Lang, P. M., Novelli, P. C., Santoni, G. W., Trainer, M., Wofsy, S. C., and Parrish, D. D.: Quantifying sources of methane using light alkanes in the Los Angeles basin, California, J. Geophys. Res.-Atmos., 118, 4974-4990, doi:10.1002/jgrd.50413, 2013.

Pickett-Heaps, C. A., Jacob, D. J., Wecht, K. J., Kort, E. A., Wofsy, S. C., Diskin, G. S., Worthy, D. E. J., Kaplan, J. O., Bey, I., and Drevet, J.: Magnitude and seasonality of wetland methane emissions from the Hudson Bay Lowlands (Canada), Atmos. Chem. Phys., 11, 3773-3779, doi:10.5194/acp-11-37732011, 2011.

Prather, M. J., Holmes, C. D., and Hsu, J.: Reactive greenhouse gas scenarios: systematic exploration of uncertainties and the role of atmospheric chemistry, Geophys. Res. Lett., 39, L09803, doi:10.1029/2012g1051440, 2012.

President's Climate Action Plan: Tech. rep., The White House, available at: http://www.whitehouse.gov/sites/default/files/ image/president27sclimateactionplan.pdf (last access: 1 December 2014), 2013.

President's Climate Action Plan: Strategy to Reduce Methane Emissions, Tech. rep., The White House, available at: http://www.whitehouse.gov/sites/default/files/strategy_to_

reduce_methane_emissions_2014-03-28_final.pdf, last access: 1 December 2014.

Ramanathan, V. and $\mathrm{Xu}$, Y.: The Copenhagen Accord for limiting global warming: criteria, constraints, and available avenues, P. Natl. Acad. Sci. USA, 107, 8055-8062, doi:10.1073/pnas.1002293107, 2010.

Rodgers, C. D.: Inverse Methods for Atmospheric Sounding, World Scientific, Singapore, 2000.

Saad, K. M., Wunch, D., Toon, G. C., Bernath, P., Boone, C., Connor, B., Deutscher, N. M., Griffith, D. W. T., Kivi, R., Notholt J., Roehl, C., Schneider, M., Sherlock, V., and Wennberg, P. O.: Derivation of tropospheric methane from TCCON $\mathrm{CH}_{4}$ and $\mathrm{HF}$ total column observations, Atmos. Meas. Tech., 7, 2907-2918, doi:10.5194/amt-7-2907-2014, 2014. 
Santoni, G. W., Xiang, B., Kort, E. A., Daubel, B. C., Andrews, A. E., Sweeney, C., Wecht, K. J., Peischl, J., Ryerson, T. B., Angevine, W. M., Trainer, M., Nehrkorn, T., Eluszkiewicz, J., Jeong, S., Fischer, M. L., Ferrare, R. A., and Wofsy, S. C.: California's methane budget derived from CalNex P-3 Aircraft Observations and a Lagrangian transport model, J. Geophys. Res., submitted, 2015.

Schepers, D., Guerlet, S., Butz, A., Landgraf, J., Frankenberg, C., Hasekamp, O., Blavier, J. F., Deutscher, N. M., Griffith, D. W. T., Hase, F., Kyro, E., Morino, I., Sherlock, V., Sussmann, R., and Aben, I.: Methane retrievals from Greenhouse Gases Observing Satellite (GOSAT) shortwave infrared measurements: performance comparison of proxy and physics retrieval algorithms, J. Geophys. Res., 117, D10307, doi:10.1029/2012jd017549, 2012.

Shindell, D., Kuylenstierna, J. C., Vignati, E., van Dingenen, R., Amann, M., Klimont, Z., Anenberg, S. C., Muller, N., JanssensMaenhout, G., Raes, F., Schwartz, J., Faluvegi, G., Pozzoli, L., Kupiainen, K., Hoglund-Isaksson, L., Emberson, L., Streets, D., Ramanathan, V., Hicks, K., Oanh, N. T., Milly, G., Williams, M., Demkine, V., and Fowler, D.: Simultaneously mitigating nearterm climate change and improving human health and food security, Science, 335, 183-189, doi:10.1126/science.1210026, 2012.

Turner, A. J. and Jacob, D. J.: Balancing aggregation and smoothing errors in inverse models, Atmos. Chem. Phys., 15, 7039-7048, doi:10.5194/acp-15-7039-2015, 2015.

van der Werf, G. R., Randerson, J. T., Giglio, L., Collatz, G. J., Mu, M., Kasibhatla, P. S., Morton, D. C., DeFries, R. S., Jin, Y., and van Leeuwen, T. T.: Global fire emissions and the contribution of deforestation, savanna, forest, agricultural, and peat fires (19972009), Atmos. Chem. Phys., 10, 11707-11735, doi:10.5194/acp10-11707-2010, 2010.

van Donkelaar, A., Martin, R. V., Pasch, A. N., Szykman, J. J., Zhang, L., Wang, Y. X., and Chen, D.: Improving the accuracy of daily satellite-derived ground-level fine aerosol concentration estimates for North America, Environ. Sci. Technol., 46, 1197111978, doi:10.1021/es3025319, 2012.

Wang, Z., Deutscher, N. M., Warneke, T., Notholt, J., Dils, B., Griffith, D. W. T., Schmidt, M., Ramonet, M., and Gerbig, C.: Retrieval of tropospheric column-averaged $\mathrm{CH}_{4}$ mole fraction by solar absorption FTIR-spectrometry using $\mathrm{N}_{2} \mathrm{O}$ as a proxy, Atmos. Meas. Tech., 7, 3295-3305, doi:10.5194/amt-7-3295-2014, 2014.

Washenfelder, R. A., Toon, G. C., Blavier, J. F., Yang, Z., Allen, N. T., Wennberg, P. O., Vay, S. A., Matross, D. M., and Daube, B. C.: Carbon dioxide column abundances at the Wisconsin Tall Tower site, J. Geophys. Res., 111, D22305, doi:10.1029/2006jd007154, 2006.

Wecht, K. J., Jacob, D. J., Wofsy, S. C., Kort, E. A., Worden, J. R., Kulawik, S. S., Henze, D. K., Kopacz, M., and Payne, V. H.: Validation of TES methane with HIPPO aircraft observations: implications for inverse modeling of methane sources, Atmos. Chem. Phys., 12, 1823-1832, doi:10.5194/acp-12-1823-2012, 2012.

Wecht, K. J., Jacob, D. J., Frankenberg, C., Jiang, Z., and Blake, D. R.: Mapping of North American methane emissions with high spatial resolution by inversion of SCIAMACHY satellite data, J. Geophys. Res.-Atmos., 119, 77417756, doi:10.1002/2014jd021551, 2014a.

Wecht, K. J., Jacob, D. J., Sulprizio, M. P., Santoni, G. W., Wofsy, S. C., Parker, R., Bösch, H., and Worden, J.: Spatially resolving methane emissions in California: constraints from the CalNex aircraft campaign and from present (GOSAT, TES) and future (TROPOMI, geostationary) satellite observations, Atmos. Chem. Phys., 14, 8173-8184, doi:10.5194/acp-14-8173-2014, 2014 b.

Wennberg, P. O., Mui, W., Wunch, D., Kort, E. A., Blake, D. R., Atlas, E. L., Santoni, G. W., Wofsy, S. C., Diskin, G. S., Jeong, S., and Fischer, M. L.: On the sources of methane to the Los Angeles atmosphere, Environ. Sci. Technol., 46, 9282-9289, doi:10.1021/es301138y, 2012.

Wofsy, S. C.: HIAPER Pole-to-Pole Observations (HIPPO): finegrained, global-scale measurements of climatically important atmospheric gases and aerosols, Philos. T. Roy. Soc. A, 369, $2073-$ 2086, doi:10.1098/rsta.2010.0313, 2011.

Wunch, D., Wennberg, P. O., Toon, G. C., Keppel-Aleks, G., and Yavin, Y. G.: Emissions of greenhouse gases from a North American megacity, Geophys. Res. Lett., 36, L15810, doi:10.1029/2009g1039825, 2009.

Wunch, D., Toon, G. C., Wennberg, P. O., Wofsy, S. C., Stephens, B. B., Fischer, M. L., Uchino, O., Abshire, J. B., Bernath, P., Biraud, S. C., Blavier, J.-F. L., Boone, C., Bowman, K. P., Browell, E. V., Campos, T., Connor, B. J., Daube, B. C., Deutscher, N. M., Diao, M., Elkins, J. W., Gerbig, C., Gottlieb, E., Griffith, D. W. T., Hurst, D. F., Jiménez, R., Keppel-Aleks, G., Kort, E. A., Macatangay, R., Machida, T., Matsueda, H., Moore, F., Morino, I., Park, S., Robinson, J., Roehl, C. M., Sawa, Y., Sherlock, V., Sweeney, C., Tanaka, T., and Zondlo, M. A.: Calibration of the Total Carbon Column Observing Network using aircraft profile data, Atmos. Meas. Tech., 3, 1351-1362, doi:10.5194/amt3-1351-2010, 2010.

Wunch, D., Toon, G. C., Blavier, J. F., Washenfelder, R. A., Notholt, J., Connor, B. J., Griffith, D. W., Sherlock, V., and Wennberg, P. O.: The total carbon column observing network, Philos. T. Roy. Soc. A, 369, 2087-112, doi:10.1098/rsta.2010.0240, 2011.

Xiao, Y., Logan, J. A., Jacob, D. J., Hudman, R. C., Yantosca, R., and Blake, D. R.: Global budget of ethane and regional constraints on US sources, J. Geophys. Res., 113, D21306, doi:10.1029/2007jd009415, 2008.

Yevich, R. and Logan, J. A.: An assessment of biofuel use and burning of agricultural waste in the developing world, Global Biogeochem. Cy., 17, 1095, doi:10.1029/2002gb001952, 2003.

Zhang, L., Jacob, D. J., Downey, N. V., Wood, D. A., Blewitt, D., Carouge, C. C., van Donkelaar, A., Jones, D. B. A., Murray, L. T., and Wang, Y.: Improved estimate of the policyrelevant background ozone in the United States using the GEOS-Chem global model with $1 / 2^{\circ} \times 2 / 3^{\circ}$ horizontal resolution over North America, Atmos. Environ., 45, 6769-6776, doi:10.1016/j.atmosenv.2011.07.054, 2011.

Zhang, L., Jacob, D. J., Knipping, E. M., Kumar, N., Munger, J. W., Carouge, C. C., van Donkelaar, A., Wang, Y. X., and Chen, D.: Nitrogen deposition to the United States: distribution, sources, and processes, Atmos. Chem. Phys., 12, 4539-4554, doi:10.5194/acp-12-4539-2012, 2012.

Zhang, L., Jacob, D. J., Yue, X., Downey, N. V., Wood, D. A., and Blewitt, D.: Sources contributing to background surface ozone in the US Intermountain West, Atmos. Chem. Phys., 14, 52955309, doi:10.5194/acp-14-5295-2014, 2014.

Zhang, Y., Jaeglé, L., van Donkelaar, A., Martin, R. V., Holmes, C. D., Amos, H. M., Wang, Q., Talbot, R., Artz, R., Brooks, 
S., Luke, W., Holsen, T. M., Felton, D., Miller, E. K., Perry, K. D., Schmeltz, D., Steffen, A., Tordon, R., Weiss-Penzias, P., and Zsolway, R.: Nested-grid simulation of mercury over North America, Atmos. Chem. Phys., 12, 6095-6111, doi:10.5194/acp12-6095-2012, 2012.
Zhao, C. F., Andrews, A. E., Bianco, L., Eluszkiewicz, J., Hirsch, A., MacDonald, C., Nehrkorn, T., and Fischer, M. L. Atmospheric inverse estimates of methane emissions from Central California, J. Geophys. Res.-Atmos., 114, D16302, doi:10.1029/2008jd011671, 2009. 